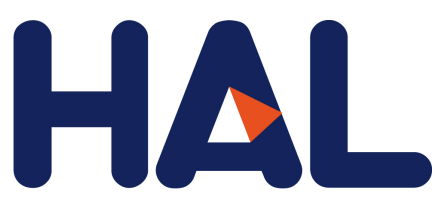

archives-ouvertes

\title{
Deprotometalation of Substituted Pyridines and Regioselectivity-Computed CH Acidity Relationships
}

Madani Hedidi, Ghenia Bentabed-Ababsa, Aicha Derdour, Yury S. Halauko,

Oleg A. Ivashkevich, Vadim E. Matulis, Floris Chevallier, Thierry Roisnel,

Vincent Dorcet, Florence Mongin

\section{To cite this version:}

Madani Hedidi, Ghenia Bentabed-Ababsa, Aicha Derdour, Yury S. Halauko, Oleg A. Ivashkevich, et al.. Deprotometalation of Substituted Pyridines and Regioselectivity-Computed CH Acidity Relationships. Tetrahedron, Elsevier, 2016, 72 (17), pp.2196-2205. 10.1016/j.tet.2016.03.022 . hal-01290443

HAL Id: hal-01290443

https://hal-univ-rennes1.archives-ouvertes.fr/hal-01290443

Submitted on 27 Apr 2016

HAL is a multi-disciplinary open access archive for the deposit and dissemination of scientific research documents, whether they are published or not. The documents may come from teaching and research institutions in France or abroad, or from public or private research centers.
L'archive ouverte pluridisciplinaire HAL, est destinée au dépôt et à la diffusion de documents scientifiques de niveau recherche, publiés ou non, émanant des établissements d'enseignement et de recherche français ou étrangers, des laboratoires publics ou privés. 


\title{
Graphical Abstract
}

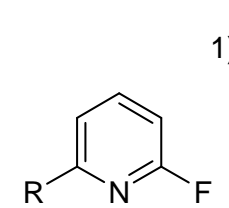

1) $\mathrm{ZnCl}_{2} \cdot$ TMEDA (1 equiv)

+ LiTMP (3 equiv)

THF, rt

2) $\mathrm{I}_{2}$

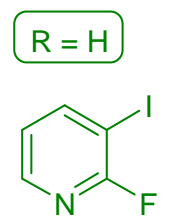

$R=F$

$82 \%$ yield

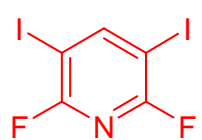

$85 \%$ yield

\section{Deprotometalation of Substituted Pyridines and}

\section{Regioselectivity-Computed CH Acidity Relationships}

\author{
Madani Hedidi, ${ }^{\mathrm{a}, \mathrm{b}}$ Ghenia Bentabed-Ababsa, ${ }^{\mathrm{b}, *}$ Aïcha Derdour, ${ }^{\mathrm{b}}$ Yury S. Halauko, ${ }^{\mathrm{c}, *}$ \\ Oleg A. Ivashkevich, ${ }^{\mathrm{c}}$ Vadim E. Matulis, ${ }^{\mathrm{d}}$ Floris Chevallier, ${ }^{\mathrm{a}}$ Thierry Roisnel, ${ }^{\mathrm{e}}$ \\ Vincent Dorcet, ${ }^{\mathrm{e}}$ and Florence Mongin ${ }^{\mathrm{a}, *}$
}

${ }^{a}$ Chimie et Photonique Moléculaires, Institut des Sciences Chimiques de Rennes, UMR 6226, Université de Rennes 1-CNRS, Bâtiment 10A, Case 1003, Campus de Beaulieu, 35042 Rennes, France

${ }^{\mathrm{b}}$ Laboratoire de Synthèse Organique Appliquée, Faculté des Sciences, Université d'Oran 1 Ahmed Ben Bella, BP 1524 El M'Naouer, 31000 Oran, Algeria

${ }^{\mathrm{c}}$ UNESCO Chair of Belarusian State University, 14 Leningradskaya Str., Minsk, 220030, Belarus

${ }^{\mathrm{d}}$ Research Institute for Physico-Chemical Problems of Belarusian State University, 14 Leningradskaya Str., Minsk, 220030, Belarus

${ }^{\mathrm{e}}$ Centre de Diffractométrie X, Institut des Sciences Chimiques de Rennes, UMR 6226, Université de Rennes 1-CNRS, Bâtiment 10B, Campus de Beaulieu, 35042 Rennes, France

* Corresponding authors. Fax: +3322323 6955.

E-mail addresses: badri_sofi@yahoo.fr (G. Bentabed-Ababsa), hys@tut.by (Y. S. Halauko), florence.mongin@univ-rennes1.fr (F. Mongin).

Keywords: $\mathrm{CH}$ acidity; pyridine; mixed lithium-zinc base; substituent effect

\begin{abstract}
:
A series of methoxy- and fluoro-pyridines have been deprotometalated in tetrahydrofuran at room temperature by using a mixed lithium-zinc combination obtained from $\mathrm{ZnCl}_{2}$. TMEDA (TMEDA = $N, N, N^{\prime}, N^{\prime}$-tetramethylethylenediamine) and LiTMP (TMP $=2,2,6,6$-tetramethylpiperidino) in a $1: 3$
\end{abstract}


ratio, and the metalated species intercepted by iodine. Efficient functionalization at the 3 position was observed from 4-methoxy, 2-methoxy, 2,6-dimethoxy, 2-fluoro and 2,6-difluoropyridine, and at the 4 position from 3-methoxy and 2,3-dimethoxypyridine. Interestingly, clean dideprotonation was noted from 3-fluoropyridine (at C2 and C4) and 2,6-difluoropyridine (at C3 and C5).

The obtained regioselectivities have been discussed in light of the $\mathrm{CH}$ acidities of the substrates, determined both in the gas phase (DFT B3LYP and G3MP2B3 levels) and in THF solution. In the case of methoxypyridines, the $\mathrm{p} K_{\mathrm{a}}$ values have also been calculated for complexes with $\mathrm{LiCl}$ and LiTMP.

\section{Introduction}

Pyridines are present in numerous biological key positions, with derivatives such as nicotine, nicotinamide (niacin), nicotinamide adenine dinucleotide phosphate (NADP) and pyridoxine (vitamin $\mathrm{B}_{6}$ ). In addition to occurring in pharmaceuticals and agrochemicals, ${ }^{1}$ pyridines are important part of organic materials. $^{2}$

To functionalize regioselectively these heterocycles, deprotonative lithiation ${ }^{3}$ appears as a valuable tool; alkyllithiums and hindered lithium dialkylamides have been largely used for this purpose. ${ }^{4}$ Nevertheless, the low compatibility between $\pi$-deficient heteroaromatics on the one hand, and either the alkyllithiums used as base or the heteroaryllithiums generated by deprotonation on the other hand, implies very low reaction temperatures and limits the scope of the method.

Alternative deprotometalation methods have since emerged with the use of metal additives allowing chemoselective reactions to be performed..$^{5}$ In the pyridine series, pioneering reagents combining alkyllithiums with LiDMAE (DMAE = 2-dimethylaminoethoxide) proved to direct the deprotonation to the 2 position. ${ }^{6}$ In addition, $(\mathrm{R})_{\mathrm{n}}\left(\mathrm{R}^{\prime}\right)_{\mathrm{n}}$,MLi-type reagents, in which $\mathrm{M}$ is a nonalkali metal (e.g. $\mathrm{Cu},{ }^{7} \mathrm{Zn}$, ${ }^{8}$ $\mathrm{Cd}^{9}$ ), have been reported for their ability to deprotometalate sensitive aromatics including pyridines.

In this context, we have developed a lithium-zinc combination, prepared from $\mathrm{ZnCl}_{2} \cdot \mathrm{TMEDA}$ $\left(\right.$ TMEDA $=N, N, N^{\prime}, N^{\prime}$-tetramethylethylenediamine $)$ and LiTMP $(\mathrm{TMP}=2,2,6,6$-tetramethylpiperidino $)$ in a 1:3 ratio, capable of accomplishing room-temperature deprotometalation of a large range of 
substrates. ${ }^{10}$ Probably in relation with high steric hindrance, this base proved by NMR and DFT studies to be a 1:1 mixture of the homometallic amides rather than a lithium zincate, ${ }^{10 a}$ a result confirmed by DOSY NMR spectroscopy. ${ }^{11}$ The idea of a deprotolithiation through LiTMP occurring first, followed by $\mathrm{Zn}(\mathrm{TMP})_{2}$-mediated transmetalation, was proposed in 2008 to rationalize its synergic behavior, ${ }^{10 a}$ and supported by others who pinpointed LiTMP. $2 \mathrm{LiCl} \pm$ TMEDA as the possible active lithiating base. ${ }^{11}$ This "trans-metal trapping" 12 has since been extended to other pairs behaving synergically such as mixtures of LiTMP on the one hand, and $\mathrm{ZnCl}_{2} \cdot 2 \mathrm{LiCl}, \mathrm{MgCl}_{2}$ or $\mathrm{CuCN} \cdot 2 \mathrm{LiCl}$ on the other hand. ${ }^{13}$

We here describe the use of this lithium-zinc combination for the deprotonative metalation of pyridines substrates and comment on the results, and notably on the regioselectivities observed, on the basis of the $\mathrm{CH}$ acidities in THF (THF = tetrahydrofuran $)$.

\section{Results and Discussion}

\section{Computational aspects}

The literature data on $\mathrm{CH}$ acidity of pyridines are scanty. ${ }^{14}$ The main reasons are the necessity of using very strong bases at low temperatures and the side reactions of the azine carbanions generated. ${ }^{4} \mathrm{~A}$ brief review of the papers devoted to experimental and theoretical investigation of azine $\mathrm{CH}$ acidities is presented in our previous publications. ${ }^{10 \mathrm{e}, 10 \mathrm{~h}}$ In the present work we report the values of $\mathrm{CH}$ acidity of pyridines both in gas-phase $\left(\Delta_{\text {acid }} G\right)$ and in THF solution $\left(\mathrm{p} K_{\mathrm{a}}\right)$, which were calculated by means of quantum chemistry.

Data on gas-phase acidity are important for the development of an acidity scale not depending on the basicity of the solvent in which the ionization takes place. Its recommended measure is the Gibbs energy $\left(\Delta_{\text {acid }} G\right)$ of deprotonation of the substance:

$$
\mathrm{R}-\mathrm{H}_{(\mathrm{g})} \rightarrow \mathrm{R}_{(\mathrm{g})}^{-}+\mathrm{H}^{+}(\mathrm{g})
$$

All the calculations were performed by using the Gaussian 03 software. Two different approaches, namely (i) the DFT B3LYP level of theory and (ii) the hybrid G3MP2B3 method, ${ }^{15}$ were used as described below. 
DFT B3LYP level of theory. The geometries were fully optimized by using the $6-31 \mathrm{G}(\mathrm{d})$ basis set. No symmetry constraints were implied and minima were found by the potential energy surface scans. In order to perform stationary point characterization and to calculate zero-point vibrational energies and thermal corrections, vibrational frequencies were calculated at the same level of theory. The single point energies were obtained using the $6-311+\mathrm{G}(\mathrm{d}, \mathrm{p})$ basis set and tight convergence criteria.

Hybrid G3MP2B3 method. G3MP2B3 is a modified version of Gaussian-3 (G3) theory for calculating energies of molecules with high accuracy. G3MP2B3 uses MP2 instead of MP4 for the basis set extension corrections and geometries and zero point vibrational energies calculated at the B3LYP/6-31G(d) level of theory.

The $\Delta_{\text {acid }} G$ values were calculated from the calculated values of Gibbs energy of species in gas phase by the following equation:

$$
\Delta_{\text {acid }} G=G_{298}^{0}\left(\mathrm{R}^{-}\right)+G_{298}^{0}\left(\mathrm{H}^{+}\right)-G_{298}^{0}(\mathrm{R}-\mathrm{H})
$$

As shown in Scheme 1, the values of the gas-phase acidity calculated at DFT B3LYP and G3MP2B3 levels are in excellent agreement (maximum deviation: $1.5 \mathrm{kcal} \mathrm{mol}^{-1}$ ), and are typical of those for very weak acids.

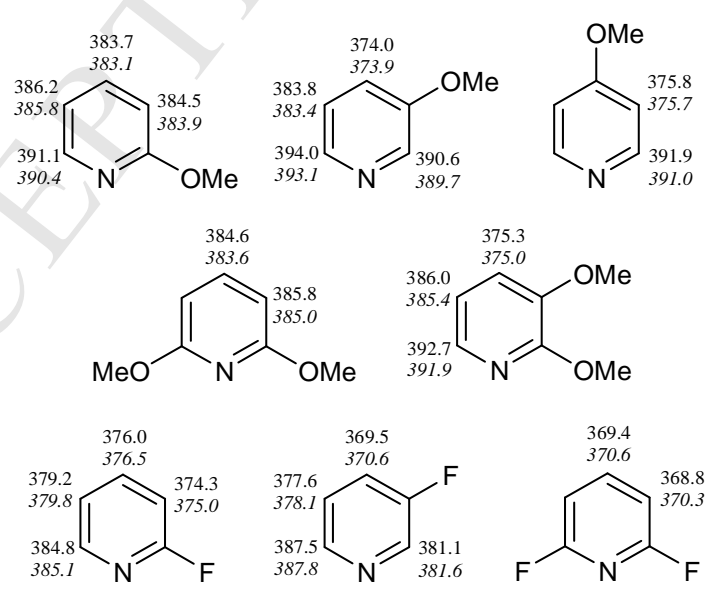

Scheme 1. Calculated $\Delta_{\text {acid }} G$ values for the studied methoxypyridines and fluoropyridines (upper straight values obtained at DFT B3LYP level, and lower italic values at G3MP2B3 level). 
The solvent effects were treated by using the IEF formalism of polarized continuum model (PCM) with the default parameters for THF. The PCM energies were calculated at the B3LYP/6-311+G(d,p) level using geometries optimized for isolated structures.

The $\mathrm{p} K_{\mathrm{a}}$ values were further calculated by means of the following homodesmic reaction:

$$
\mathrm{R}-\mathrm{H}_{(\mathrm{s})}+\mathrm{Py}_{(\mathrm{s})}^{-} \rightarrow \mathrm{R}_{(\mathrm{s})}^{-}+\mathrm{Py}-\mathrm{H}_{(\mathrm{s})},
$$

where $\mathrm{Py}-\mathrm{H}$ is bare pyridine, whose $\mathrm{p} K_{\mathrm{a}}$ value in THF $(40.2$, for position 4 of the ring) is known experimentally.

The homodesmic reaction Gibbs energy was calculated using the following equation:

$$
\Delta_{\mathrm{r}} G_{\mathrm{s}}=\sum_{\text {products }} G_{\mathrm{s}}-\sum_{\text {reactants }} G_{\mathrm{s}} .
$$

Further, it can be proved that:

$$
\mathrm{p} K_{\mathrm{a}}(\mathrm{R}-\mathrm{H})=40.2+\frac{\Delta_{r} G_{s}}{R T} \cdot \frac{1}{\ln 10} .
$$

The $\mathrm{CH}$ acidity values for fluoro- and methoxy-pyridines in THF solution can be compared with those previously determined for chloro- and bromo-pyridines (Table 1). ${ }^{10 \mathrm{e}}$

Table 1. Pyridine $\mathrm{p} K_{\mathrm{a}}(\mathrm{THF})$ changes caused by substituent effects.

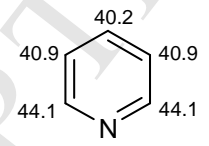<smiles>[X]c1ccccn1</smiles>

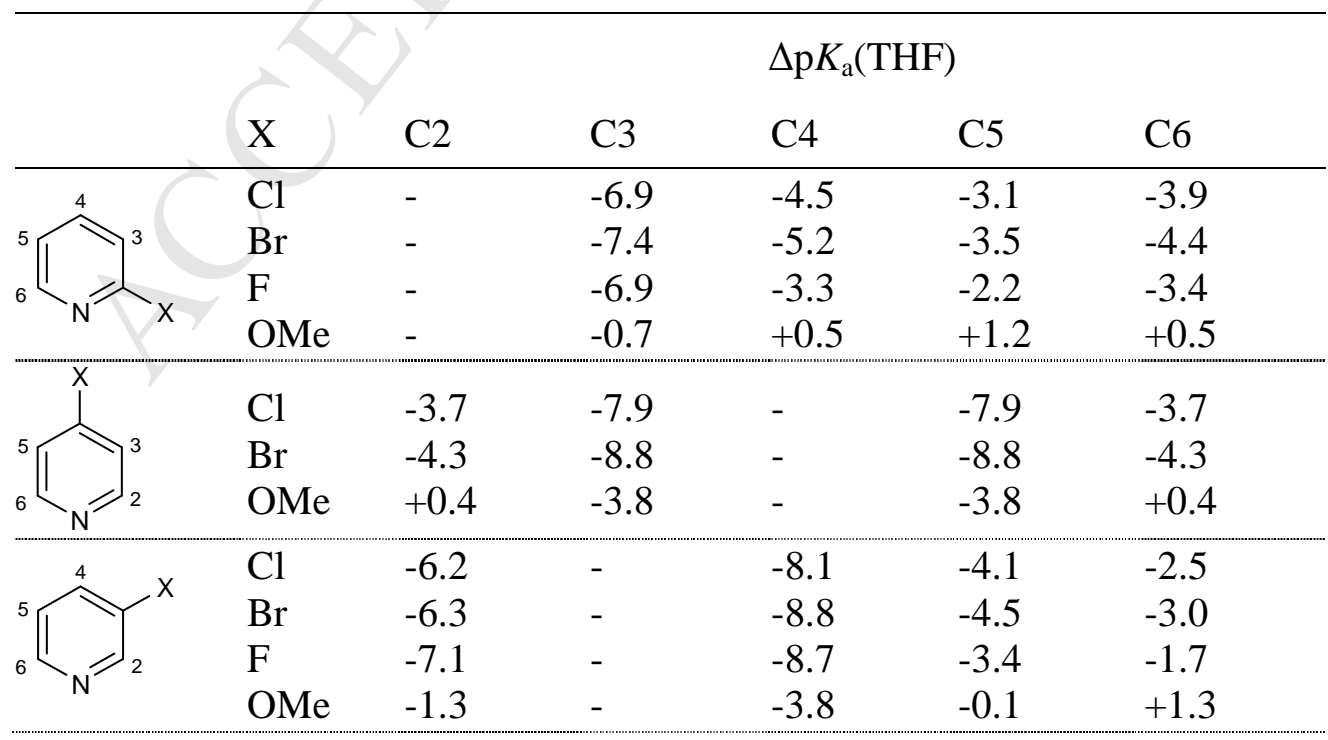




\begin{tabular}{lllllll}
$\mathrm{Cl}$ & - & -9.3 & -8.4 & -9.3 & - \\
$\mathrm{Br}$ & - & -9.9 & -9.7 & -9.9 & - \\
$\mathrm{F}$ & - & -9.0 & -6.4 & -9.0 & - \\
$\mathrm{O}$ & - & +0.7 & +1.2 & +0.7 & - \\
$\mathrm{OMe}$ & - & - & - & -11.3 & -6.4 & -6.2 \\
& $\mathrm{Cl}$ & - & - & -12.2 & -7.0 & -6.8 \\
& $\mathrm{Br}$ & - & -3.0 & +1.4 & +1.6 \\
\hline
\end{tabular}

While the values of $\mathrm{p} K_{\mathrm{a}}(\mathrm{THF})$ of methoxypyridines are rather high and are of magnitude of monosubstituted benzenes ${ }^{16}$ the insertion of halogen makes the compounds much more acidic. When present at the 2 position, fluorine exerts a short range effect similar to that of chlorine; in contrast, positions remote from fluorine are less acidified (than with chlorine and, above all, bromine), in agreement with the electronic effects of the substituents. ${ }^{17}$ The influence of the methoxy group is not quite that prominent. For molecules containing a methoxy group at the 2-, 4- and even 3-position, only adjacent sites are acidified. That the strongest acidifying effect is observed at both 2- and 4-sites, neighboring to the substituent, is a general trend for 3-substituted pyridines. In addition, this effect is stronger at the 4-position, which is far from the nitrogen lone pair, and also more affected because of concordant halogen/methoxy and nitrogen effects. In the case of 2,6-dihalogenated pyridines, the strongest acidifying effect is observed at the 3-and 5-positions of the ring. In addition, the 4-position also becomes much more acidic, notably compared to 2-monohalogenated substances, because of the cooperative long range electron-withdrawing effects of both halogens. With 2,6-dimethoxypyridine, the short range $-I$ effects exhibited at the 3- and 5-position of the cycle by the methoxy groups are concealed by their stronger long range "para" electron-donating $(+M)$ effects. From 2,3dimethoxypyridine, the "meta" electron-donating effect exhibited by the methoxy group at C2 does not offset the short range inductive acidifying effect exerted at $\mathrm{C} 4$ by the methoxy group at $\mathrm{C} 3$; as a result, the 4 position is more acidified for 2,3-dimethoxypyridine than for 2,6-dimethoxypyridine.

By using the computational approach described above, we also investigated the influence of substrate coordination to lithium species on the $\mathrm{p} K_{\mathrm{a}}(\mathrm{THF})$ values (Figure 1). It is worth noting that, besides impacting the $\mathrm{p} K_{\mathrm{a}}(\mathrm{THF})$ values, complexation to lithium can favor the deprotonation at a neighboring 
site through complex-induced proximity effect. ${ }^{18}$ To this purpose, we considered 1:1 complexes of 3-, 4- and 2-methoxypyridine with $\mathrm{LiCl}$ and LiTMP. With $\mathrm{LiCl}$, two types of coordination - namely through nitrogen and oxygen - were investigated, and several trends can be noted here. As expected, coordination of methoxypyridine to $\mathrm{LiCl}$ by nitrogen is more effective than by oxygen (with the corresponding isomeric complexes up to $8 \mathrm{kcal} \mathrm{mol}^{-1}$ more stable). In the case of O-Li complexation, the anions formed under deprotonation at positions adjacent to the methoxy group benefit from additional cyclic stabilization (values with asterisk on Figure 1). Finally, coordination of the metal by the ring nitrogen lone pair drastically increases $\mathrm{CH}$ acidity of the adjacent positions, making them competitive in deprotometalation processes.

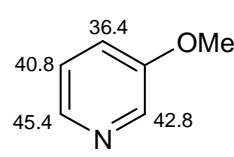

$1 \mathbf{a}$<smiles>COc1ccncc1Br</smiles>

$3 a$

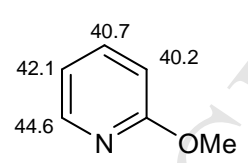

$4 a$<smiles>COc1cccnc1</smiles><smiles>OCCOc1cnccc1OCl</smiles><smiles>COc1ncccc1Br</smiles><smiles>CCN1C=CC=C(OC)N1[Al]Cl</smiles><smiles></smiles><smiles></smiles>

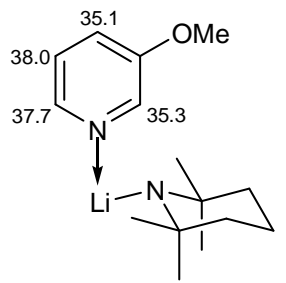<smiles>COc1cc[n+]([Al]2NC3(C)CCCC2(C)C3)cc1</smiles><smiles>COc1ccc[n+]([Al]2NC3(C)CCC2(C)CC3)c1</smiles>

Figure 1. Calculated $\mathrm{p} K_{\mathrm{a}}(\mathrm{THF})$ values for 3-, 4- and 2-methoxypyridine, as well as their complexes with $\mathrm{LiCl}$ or/and LiTMP.

\section{Synthetic aspects}

We first focused on the deprotometalation of 3-methoxypyridine (1a). 1a can be deprotolithiated regioselectively at its 2 position by using BuLi-TMEDA in THF at $-40{ }^{\circ} \mathrm{C}$, as evidenced by trapping 
with acetaldehyde to afford the expected alcohol in $49 \%$ yield. ${ }^{19}$ A favored coordination of the metal of the base by the ring nitrogen (when compared to the methoxy substituent) is advanced to rationalize this result. By increasing the deprotometalation temperature to $-23{ }^{\circ} \mathrm{C}$, which proves possible by using less nucleophilic mesityllithium, 2-substituted 3-methoxypyridines are formed in higher yields. ${ }^{20}$ Using LiDA (DA = diisopropylamino) in THF at $-42{ }^{\circ} \mathrm{C}$ only proves efficient in the presence of chlorotrimethylsilane as an in situ trap, but mainly gives rise to a mixture of the 2- and 4-substituted derivatives (assumed to be the kinetic and thermodynamic products, respectively). ${ }^{20}$

Magnesation of 3-methoxypyridine (1a) can be achieved selectively at its 4 position by using a dipotassium tetra(alkyl)magnesate including a polydentate $\mathrm{N}$-donor, (PMDETA) ${ }_{2} \mathrm{~K}_{2} \mathrm{Mg}\left(\mathrm{CH}_{2} \mathrm{SiMe}_{3}\right)_{4}$ $\left(\right.$ PMDETA $=N, N, N$, $N$ ", $N "$-pentamethyldiethylenetriamine), in hexane at $0{ }^{\circ} \mathrm{C}^{21}$ Similarly, $\mathbf{1 a}$ can be 4-zincated by using Kondo and Uchiyama's TMP-zincate, $\operatorname{Li}(\mathrm{TMP}) \mathrm{Zn}(t \mathrm{Bu})_{2},{ }^{22}$ in THF at $25{ }^{\circ} \mathrm{C} .{ }^{23}$

The 1:1 mixture of LiTMP and $\mathrm{Zn}(\mathrm{TMP})_{2}$, obtained from $\mathrm{ZnCl}_{2} \cdot$ TMEDA and LiTMP, ${ }^{10 a, 11}$ was involved in the reaction with 1a in order to better understand the behavior of this combination (Table 2). Upon treatment by the base ( 0.5 equiv of each metal amide) in THF for $2 \mathrm{~h}$ at room temperature (or $0{ }^{\circ} \mathrm{C}$ ) and subsequent trapping with iodine, 1a was converted to a mixture of the 2- and 4-iodo derivatives (1b and 1c), both purified, isolated in 10 and 85\% yield, respectively (entry 1). In order to see if this ratio could be modified, reactions were performed at a lower temperature or using a shorter reaction time. Whereas no reaction was noted at $-40{ }^{\circ} \mathrm{C}$ (entry 2 ), shortening the reaction time to $10 \mathrm{~min}$ led to a mixture of $\mathbf{1 b}(50 \%$ yield) and $\mathbf{1 c}$ (25\% yield) (entry 3$)$. By keeping a $2 \mathrm{~h}$ contact at room temperature with the base, extending the base amount to 1 equiv of each metal amide led to the competitive formation of the 2,4-diiodo derivative 1d (30\% yield, entry 4). With 2 equiv of each metal amide, 1c (58\% yield) and 1d (35\% yield) were the only products isolated (entry 5); in spite of caking of the reaction mixture, the formation of $\mathbf{1 d}$ proved favored by extending the contact time between base and substrate to $20 \mathrm{~h}$ (entry 6). ${ }^{10 \mathrm{~h}}$ By using LiTMP (2 equiv) under similar reaction conditions, the 4iodo derivative 1c was obtained in $6 \%$ yield together with traces of $\mathbf{1 b}$ and the $4,4^{\prime}-$ dimer $^{24}(25 \%$ 
yield). Upon a similar treatment but in the presence of TMEDA (2 equiv), 1c and the 4,4'-dimer formed in 5 and $11 \%$ yield, respectively, together with traces of $\mathbf{1 b .}$

Table 2. Calculated $\mathrm{p} K_{\mathrm{a}}(\mathrm{THF})$ values for 3-methoxypyridine (1a), deprotometalation using in situ prepared 1:1 LiTMP-Zn(TMP) $)_{2}$ followed by iodolysis and ORTEP diagram (30\% probability) of $\mathbf{1 d}$.

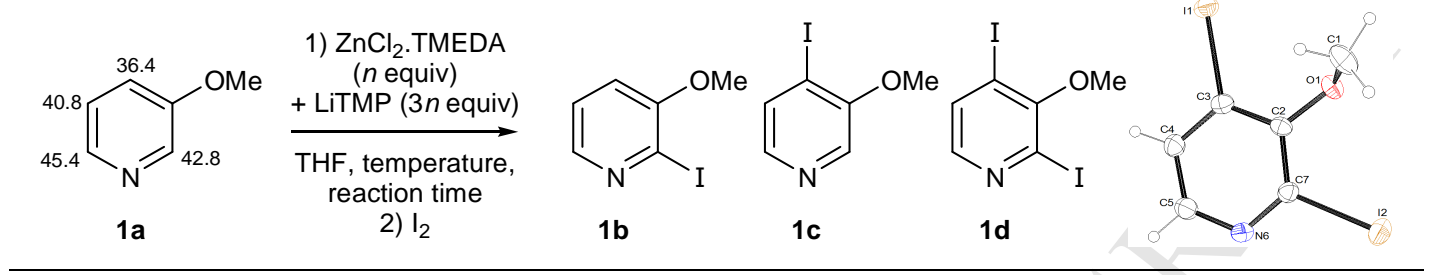

\begin{tabular}{|c|c|c|c|c|c|c|}
\hline Entry & $n$ (equiv) & Temperature $\left({ }^{\circ} \mathrm{C}\right)$ & Reaction time & \multicolumn{3}{|c|}{ Products, yields (\%) } \\
\hline 1 & 0.5 & $20^{a}$ & $2 \mathrm{~h}$ & $\mathbf{1 b}, 10^{b}$ & 1c, $85^{b}$ & - \\
\hline 2 & 0.5 & -40 & $2 \mathrm{~h}$ & $-\sqrt{-3}$ & - & - \\
\hline 3 & 0.5 & 20 & $10 \mathrm{~min}$ & $\mathbf{1 b}, 50^{b}$ & $1 \mathrm{c}, 25^{b}$ & - \\
\hline 4 & 1 & 20 & $2 \mathrm{~h}$ & $1 \mathrm{~b}, 11^{b}$ & $1 c, 50^{b}$ & 1d, $30^{b}$ \\
\hline 5 & 2 & 20 & 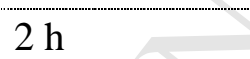 & - & $1 c, 58^{b}$ & 1d, $35^{b}$ \\
\hline 6 & 2 & 20 & $20 \mathrm{~h}$ & - & $1 \mathrm{c}, 45^{c}$ & $1 \mathrm{~d}, 55^{c}$ \\
\hline
\end{tabular}

${ }^{a}$ A similar result was obtained at $0{ }^{\circ} \mathrm{C}$ and using $\mathrm{Et}_{2} \mathrm{O}$ as solvent at room temperature. ${ }^{b}$ Yield after purification by column chromatography. ${ }^{c}$ Ratio determined from the ${ }^{1} \mathrm{H}$ NMR spectrum of the crude.

Some conclusions can be drawn from these data. The different results above confirm that the 2- and 4-metalated 3-methoxypyridines correspond to kinetic and thermodynamic products, respectively. The kinetic products are observed by using organolithiated (alkyl/aryl) bases, and coordination of the ring nitrogen to lithium favors reaction at $\mathrm{C} 2$ by both proximity effect ${ }^{18 \mathrm{a}}$ and strongly decreasing of the corresponding $\mathrm{p} K_{\mathrm{a}}$ values (Figure 1). Results also evidence formation of transient 2-metalated 3methoxypyridines by using amido-containing bases such as LiDA, LiTMP and 1:1 LiTMP-Zn(TMP) $)_{2}$. If chlorotrimethylsilane is not present to intercept the 2-metalated species, they change to presumably more stable 4-metalated derivatives (reversible reactions). Such an isomerization could also take place by using TMP-zincate, with lithium coordination by the pyridine nitrogen first giving rise to a 2metalated species, ${ }^{25}$ provided that this conversion is faster than the consumption of generated H-TMP by the tert-butyl ligands. ${ }^{26}$ 
The formation of 2,4-dimetalated species is only observed by using 1:1 LiTMP-Zn(TMP) $)_{2}(1$ or 2 equiv) for which "trans-metal trapping"12 can take place. If lithium is coordinated by the pyridine nitrogen in the 2-metalated 3-methoxypyridine, methoxy could be still available to stabilize a 4metalated species. Similarly, if lithium is coordinated by the methoxy group in the 4-metalated 3methoxypyridine, pyridine nitrogen could be free to play a role in the formation of a 2-metalated derivative (Scheme 2).

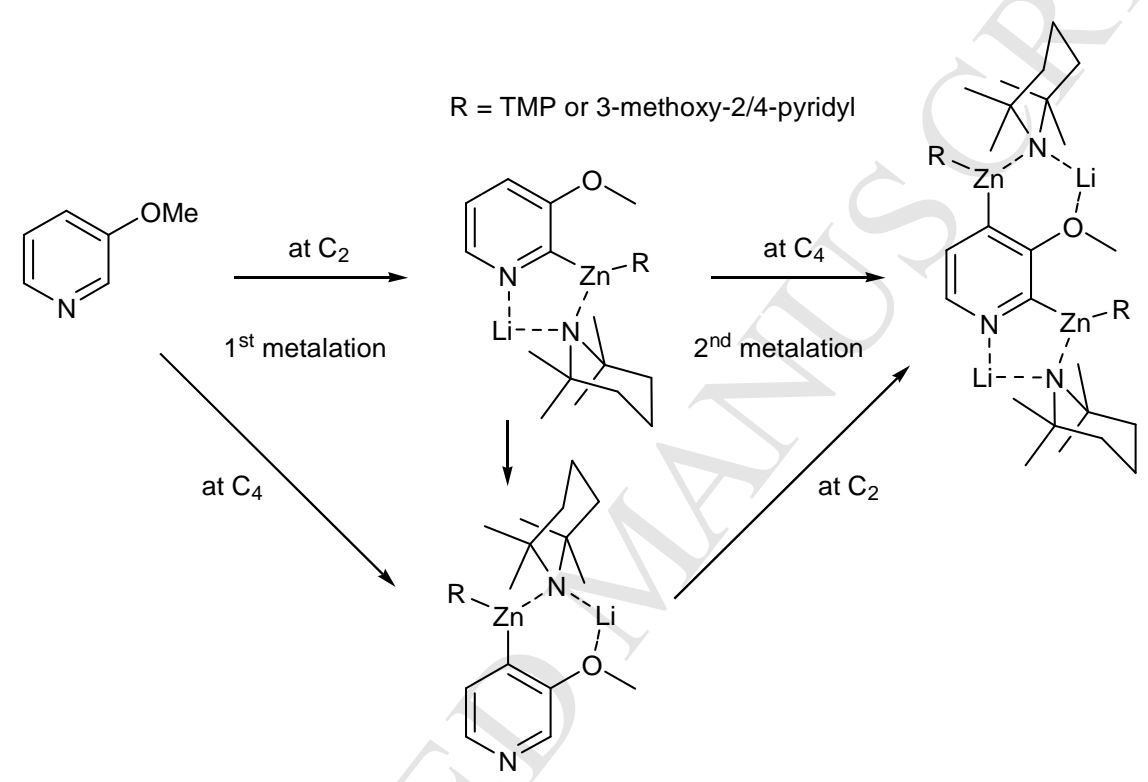

Scheme 2. Proposed pathways to the 2,4-dimetalated 3-methoxypyridine.

By contrast with 1a, for which deprotometalation is observed at C4 by using 1:1 LiTMP-Zn(TMP $)_{2}$ in THF at room temperature for $2 \mathrm{~h}, 3$-chloro and 3-bromopyridine are attacked at $\mathrm{C} 2$ under similar conditions. ${ }^{10 \mathrm{e}}$ Such a difference could be in relation with a higher ability to coordinate lithium in the case of the methoxy group, contributing to a greater stabilization of the corresponding 4-metalated derivative, as shown in Figure 2. 


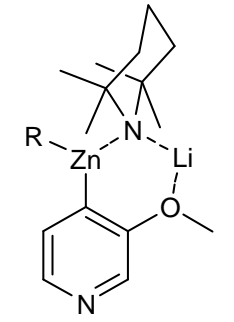

$\mathrm{R}=\mathrm{TMP}$ or

3-methoxy-4-pyridyl

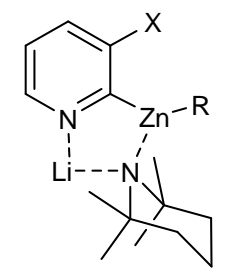

$\mathrm{X}=\mathrm{Cl}, \mathrm{Br} ; \mathrm{R}=\mathrm{TMP}$ or 3-substituted 2-pyridyl

Figure 2. Proposed metalated species for 3-methoxy, 3-chloro and 3-bromopyridine.

This difference led us to study the behavior of 3-fluoropyridine (2a). 2a reacts with BuLi·TMEDA at $-40{ }^{\circ} \mathrm{C}$ to afford either the 2- (kinetic) or the 4- (thermodynamic) lithio species, depending on if $\mathrm{Et}_{2} \mathrm{O}$ or more polar THF is respectively employed as solvent; the isomerization was supposed to occur through the formation of the 2,4-dilithio species. $^{27}$ The use of BuLi.DABCO (DABCO $=1,4-$ diazabicyclo[2.2.2] octane) in $\mathrm{Et}_{2} \mathrm{O}$ at $-75{ }^{\circ} \mathrm{C}$ allows $\mathbf{2 a}$ to be selectively attacked next to nitrogen. ${ }^{27 \mathrm{~b}}$ In contrast, 2a gives 4-substituted products by using LiDA in THF at $-75^{\circ} \mathrm{C} .{ }^{28,27 b}$ A similar regioselectivity can be reached by using $\mathrm{BuLi} \cdot t \mathrm{BuOK}$ in $\mathrm{THF}$ at $-75{ }^{\circ} \mathrm{C}^{29}$ and $\mathrm{LiMgBu}$ in $\mathrm{THF}$ at -10 ${ }^{\circ} \mathrm{C} .{ }^{30}$

Thus, 3-fluoropyridine (2a) was involved in the reaction with the 1:1 mixture of LiTMP and $\mathrm{Zn}(\mathrm{TMP})_{2}$ (Table 3$)$. After $2 \mathrm{~h}$ contact with the base (0.5 equiv of each metal amide) in THF at room temperature, iodolysis furnished a mixture of the 2- and 4-iodo derivatives (2b and $\mathbf{2 c}$ ) in 57 and $37 \%$ yield, respectively (entry 1). Compared with methoxy (see above) and the other halogens (chlorine, bromine), ${ }^{10 \mathrm{e}}$ fluorine at $\mathrm{C} 3$ is less capable than the former and more than the latter of contributing to the stabilization of a 4-metalated species; thus, its ability to coordinate and stabilize a 4-metalated derivative seems to be intermediate between methoxy and the other halogens.

Increasing the base amount (to 1 equiv of each metal amide) allowed the diiodide $\mathbf{2 d}$ to be obtained in $46 \%$ yield together with the 4-iodo $\mathbf{2 c}$ (45\% yield) and the 2-iodo $\mathbf{2 b}$ (9\% yield). The experiment carried out by using 2 equiv of each metal amide quantitatively provided the diiodo $2 \mathbf{d}$ (entry 3 ); this result is different to what is observed from 1a, and can be in relation with lower $\mathrm{p} K_{\mathrm{a}}$ values. 
Table 3. Calculated $\mathrm{p} K_{\mathrm{a}}(\mathrm{THF})$ values for 3-fluoropyridine (2a), and deprotometalation using in situ prepared 1:1 LiTMP-Zn(TMP) $)_{2}$ followed by iodolysis and ORTEP diagram (30\% probability) of $\mathbf{2 d}$.

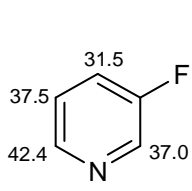

2a

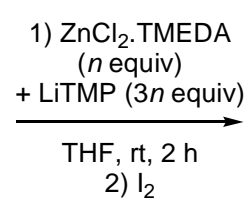

2) $\mathrm{I}_{2}$<smiles>Fc1cccnc1I</smiles>

$2 b$<smiles>Fc1cnccc1I</smiles>

2c<smiles>Fc1c(I)ccnc1I</smiles>

2d

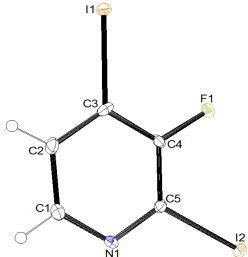

\begin{tabular}{lllll}
\hline Entry & $n$ (equiv) & \multicolumn{4}{l}{ Products, yields ${ }^{a}(\%)$} \\
\hline 1 & 0.5 & $\mathbf{2 b}, 57$ & $\mathbf{2 c}, 37$ & $\mathbf{2 d}, 1$ \\
\hline 2 & 1 & $\mathbf{2 b}, 9$ & $\mathbf{2 c}, 45$ & $\mathbf{2 d}, 46$ \\
\hline 3 & 2 & $\mathbf{2 b},-$ & $\mathbf{2 c}, 6$ & $\mathbf{2 d}, 94$ \\
\hline
\end{tabular}

${ }^{a}$ Yield after purification by column chromatography.

We next focused on 4- and 2-methoxypyridines (3a and 4a). Concerning 4-methoxypyridine (3a), using LiDA in THF in the presence of chlorotrimethylsilane leads to the 3-silylated derivative $(61 \%$ yield) together with the 3,5 -disilylated $(16 \%) .{ }^{20}$ Deprotolithiation can be carried out at the 3 position more efficiently by using either mesityllithium in THF at $-23{ }^{\circ} \mathrm{C}^{20}$ or phenyllithium in THF at $0{ }^{\circ} \mathrm{C} .{ }^{31}$

Due to lower LUMO levels, 2-methoxypyridine (4a) is more prone to nucleophilic attacks than 3-and 4-methoxypyridines (1a and 3a). ${ }^{32}$ Using BuLi in THF with 4a at temperatures between 0 and $20{ }^{\circ} \mathrm{C}$ leads to both deprotolithiation and nucleophilic addition. ${ }^{33}$ Conducting the reaction by using LiDA and chlorotrimethylsilane as an in situ trap quantitatively furnishes the 3-trimethylsilyl derivative. ${ }^{32}$ To make efficient this LiDA-promoted deprotometalation, and extend it to other kinds of electrophilic trapping, it is possible to consume the diisopropylamine formed by reaction either with $\mathrm{MeLi}^{32}$ or with PhLi. $^{34}$ As for 3-methoxypyridine (1a), mesityllithium can be used in THF at room temperature. ${ }^{20}$ Bimetallic combinations such as 1:1 LiTMP-Al $(i \mathrm{Bu})_{3}$ ("trans-metal trapping",12 in THF at $\left.-78{ }^{\circ} \mathrm{C}\right),{ }^{35}$ putative $\mathrm{LiCo}(\mathrm{TMP})_{3}$ (in THF at room temperature) ${ }^{36} \mathrm{LiCu}(\mathrm{TMP})_{2}$ (in $\mathrm{THF}$ at room temperature) ${ }^{37}$ and putative $\mathrm{LiFe}(\mathrm{TMP})_{3}$ (in THF at room temperature), ${ }^{38}$ can be employed for the same purpose. The regioselectivity of the reaction can be switched from the more acidic 3 to the less acidic 6 position by recourse to $\mathrm{BuLi}$-LiDMAE in hexane at $0{ }^{\circ} \mathrm{C}$, conditions that favor coordination- over acidity-driven reaction. ${ }^{39}$ 
As previously for 3-methoxypyridine (1a), 4- and 2-methoxypyridines (3a and 4a) can be converted to the 3-iodo derivatives either in 58 and $70 \%$ yield, respectively, by using $(\mathrm{PMDETA})_{2} \mathrm{~K}_{2} \mathrm{Mg}\left(\mathrm{CH}_{2} \mathrm{SiMe}_{3}\right)_{4}$ in hexane at $0{ }^{\circ} \mathrm{C},{ }^{21}$ or in 92 and $70 \%$ yield by using TMP-zincate in THF at room temperature. ${ }^{23}$

Upon treatment by the $1: 1$ mixture of LiTMP and $\mathrm{Zn}(\mathrm{TMP})_{2}(0.5$ equiv of each metal amide $)$ in THF for $2 \mathrm{~h}$ at room temperature followed by quenching with iodine, 4-methoxypyridine (3a) cleanly provided the 3 -iodo derivative $\mathbf{3 b}$, which was isolated in $89 \%$ yield (Table 4 , entry 1 ). When the amount of base was increased to 1 equiv of each metal amide, no more starting material was detected but 3,5-diiodo-4-methoxypyridine 3c (7\% yield), 2,3-diiodo-4-methoxypyridine 3d (2\% yield) and 2,5diiodo-4-methoxypyridine $\mathbf{3 e}$ (traces) concomitantly formed with the monoiodide $\mathbf{3 b}$ ( $88 \%$ yield) (Table 4, entry 2). It is worth mentioning that, by using LiTMP (1.5 equiv) without Zn(TMP $)_{2}$ in THF at $0{ }^{\circ} \mathrm{C}$ for $2 \mathrm{~h}$, the yield of $\mathbf{3 b}$ dropped to $38 \%$ again demonstrating the value of the "trans-metal trapping" $" 12$ approach.

Table 4. Calculated $\mathrm{p} K_{\mathrm{a}}(\mathrm{THF})$ values for 4-methoxypyridine (3a), and deprotometalation using in situ prepared 1:1 LiTMP-Zn(TMP $)_{2}$ followed by iodolysis.<smiles>COc1ccncc1</smiles>
1) $\begin{gathered}\mathrm{ZnCl}_{2} \cdot \text { TMEDA } \\ (n \text { equiv })\end{gathered}$
$+\underset{\text { LiTMP ( } 3 n \text { equiv) }}{\longrightarrow}$
$\underset{\mathrm{THF}, \mathrm{rt}, 2 \mathrm{~h}}{\text { 2) } \mathrm{I}_{2}}$<smiles>COc1ccncc1[IH]c1cncc(I)c1OC</smiles>

$3 b$<smiles>COc1ccnc(I)c1I</smiles>

3d<smiles>COc1cc(I)ncc1I</smiles>

$3 e$

\begin{tabular}{llllll} 
3a & \multicolumn{1}{c}{ 3b } & 3c & 3d & \multicolumn{1}{c}{ 3e } \\
\hline Entry & $n$ (equiv) & \multicolumn{2}{l}{ Products, yields ${ }^{a}(\%)$} & & \\
\hline 1 & 0.5 & 3b, 89 & $\mathbf{3 c},-$ & 3d, - & 3e, - \\
\hline 2 & 1 & 3b, 88 & $\mathbf{3 c}, 7$ & 3d, 2 & 3e, traces \\
\hline
\end{tabular}

${ }^{a}$ Yield after purification by column chromatography.

Under the same reaction conditions, 1:1 LiTMP-Zn(TMP $)_{2}(0.5$ equiv of each metal amide $)$ converted 2-methoxypyridine (4a) into the 3 -iodo derivative $\mathbf{4 b}$ but in a moderate $31 \%$ yield (Table 5 , entry 1 ), a result that could be due to higher $\mathrm{p} K_{\mathrm{a}}$ values at the 3 position. A quantitative yield was reached by 
doubling the amount of base (Table 5, entry 2). Such a result could not be reproduced by using LiTMP, even in the presence of $\mathrm{LiCl}$.

Table 5. Calculated $\mathrm{p} K_{\mathrm{a}}(\mathrm{THF})$ values for 2-methoxypyridine (4a), and deprotometalation using in situ prepared 1:1 LiTMP-Zn(TMP $)_{2}$ followed by iodolysis.

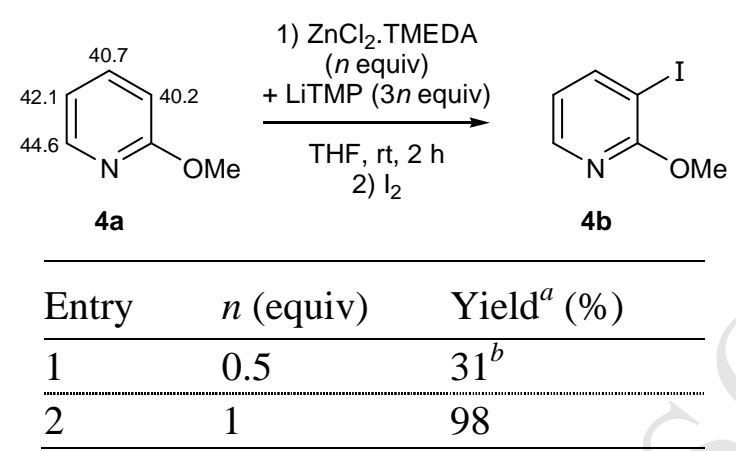

${ }^{a}$ Yield after purification by column chromatography. ${ }^{b}$ The rest is starting material.

Compared with 2-methoxypyridine (4a), 2-fluoropyridine (5a) is more reactive. Alkyllithiums already add nucleophilically to the latter at low temperatures, e.g. $\mathrm{BuLi} \cdot \mathrm{TMEDA}$ in $\mathrm{Et}_{2} \mathrm{O}$ at $-40{ }^{\circ} \mathrm{C}$ and, to a lesser extent, $\mathrm{BuLi}$ in $\mathrm{Et}_{2} \mathrm{O}$ at $-60{ }^{\circ} \mathrm{C} .{ }^{40}$ In contrast, using more protophilic $\mathrm{LiDA}^{40-41}$ or $\mathrm{BuLi} \cdot t \mathrm{BuOK},{ }^{29}$ both in $\mathrm{THF}$ at $-75{ }^{\circ} \mathrm{C}$, favors proton abstraction (which occurs next to fluorine). Turning to $\mathrm{Li}_{2}$ (TMP)MgBu $3{ }^{30}$ and $\mathrm{LiCu}(\mathrm{TMP})_{2}{ }^{37}$ in $\mathrm{THF}$ allows 5 a to be deprotometalated at $-10{ }^{\circ} \mathrm{C}$ and rt, respectively.

This higher reactivity of 2-fluoropyridine (5a) over $\mathbf{4 a}$, probably in relation with lower $\mathrm{p} K_{\mathrm{a}}$ values, was here evidenced by reaction with $1: 1 \mathrm{LiTMP}-\mathrm{Zn}(\mathrm{TMP})_{2}$ to give under the same reaction conditions 2-fluoro-3-iodopyridine (5b) as the main product together with $15 \%$ of 2-fluoro-3,6-diiodopyridine (5c) (Table 6). Once again, the behavior of fluorine is intermediate between those of the methoxy group and the other halogens (chlorine, bromine). Indeed, for the latter, not only 2-halo-3-iodo and 2-halo-3,6diiodo derivatives are formed, but also 2-halo-6-iodo and 2-halo-4-iodo derivatives. ${ }^{10 \mathrm{e}}$ 
Table 6. Calculated $\mathrm{p} K_{\mathrm{a}}(\mathrm{THF})$ values for 2-fluoropyridine (5a), and deprotometalation using in situ prepared 1:1 LiTMP-Zn(TMP $)_{2}$ followed by iodolysis.

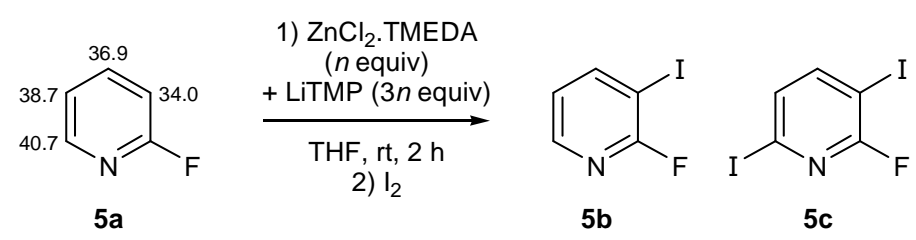

\begin{tabular}{llll}
\hline Entry & $n$ (equiv) & \multicolumn{2}{c}{ Products, yields ${ }^{a}(\%)$} \\
\hline 1 & 0.5 & $\mathbf{5 b}, 66$ & $\mathbf{5 c}, 15$ \\
\hline 2 & 1 & $\mathbf{5 b}, 82$ & $\mathbf{5 c}, 15$ \\
\hline \multicolumn{2}{r}{ Yield after purification by column chromatography. }
\end{tabular}

Compared with 2-methoxypyridine (4a), 2,6-dimethoxypyridine (6a) is less prone to nucleophilic attacks. BuLi can thus be employed to functionalize efficiently the 3 position. ${ }^{42}$ The bimetallic base $\mathrm{LiCo}(\mathrm{TMP})_{3}$ can also be used in THF at room temperature for the same purpose. ${ }^{36}$ In the case of $2,3-$ dimethoxypyridine (7a), 2 equiv of BuLi are required to perform an efficient functionalization at the 4 position. $^{43}$

Both compounds $\mathbf{6 a}$ and $7 \mathbf{a}$ could be quantitatively deprotometalated next to the methoxy group by using 1:1 LiTMP-Zn(TMP) 2 (1 equiv of each metal amide), a result evidenced by subsequent iodolysis. From 6a, dimetalation was only observed when the amount of base was doubled and the reaction time extended to $20 \mathrm{~h}$. Reducing the amount of base in the case of $7 \mathbf{a}$ led to a lower $20 \%$ yield (Scheme 3 ).

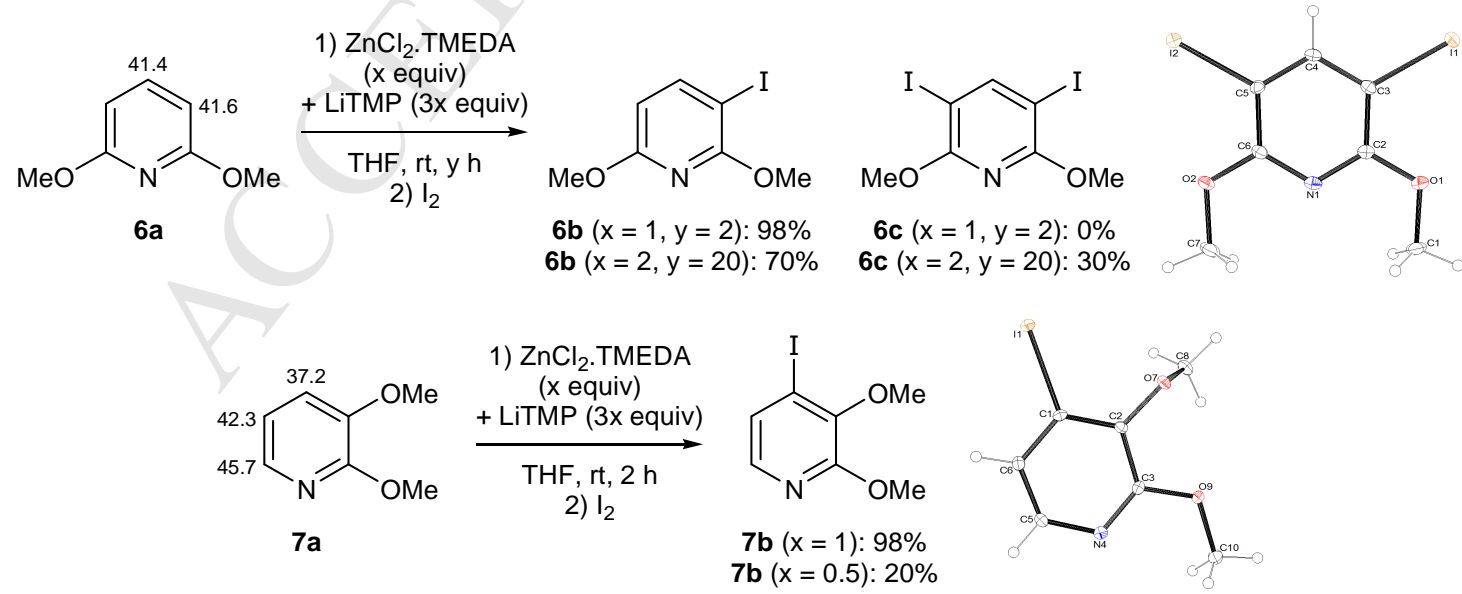

Scheme 3. Calculated $\mathrm{p} K_{\mathrm{a}}(\mathrm{THF})$ values for 2,6-dimethoxypyridine (6a) and 2,3-dimethoxypyridine (7a), deprotometalation using in situ prepared 1:1 LiTMP-Zn(TMP $)_{2}$ followed by iodolysis and ORTEP diagram (30\% probability) of $\mathbf{6 c}$ and $\mathbf{7 b}$. 
We finally studied the behavior of 2,6-difluoropyridine (8a). 8a can be cleanly deprotolithiated at its 3 position upon treatment with LiDA in THF at $-75^{\circ} \mathrm{C} .{ }^{44,41 \mathrm{~b}, \mathrm{c}} \mathrm{A}$ similar reaction is also possible by using $\mathrm{Li}_{2}$ (TMP) $\mathrm{MgBu}_{3}$ in THF at $-10{ }^{\circ} \mathrm{C} .{ }^{30}$ In contrast to what can be observed by employing LiDA, using 1:1 LiTMP-Zn(TMP $)_{2}$ in THF at room temperature led either to mono or to dideprotonation $(0.5$ or 1 equiv of each metal amide, respectively) of 2,6-difluoropyridine (8a), as demonstrated by subsequent interception with iodine to furnish either the monoiodide $\mathbf{8 b}$ ( $66 \%$ yield) or the diiodide $\mathbf{8 c}$ (85\% yield) (Table 7$)$.

Table 7. Calculated $\mathrm{p} K_{\mathrm{a}}(\mathrm{THF})$ values for 2,6-difluoropyridine (8a), and deprotometalation using in situ prepared 1:1 LiTMP-Zn(TMP $)_{2}$ followed by iodolysis.
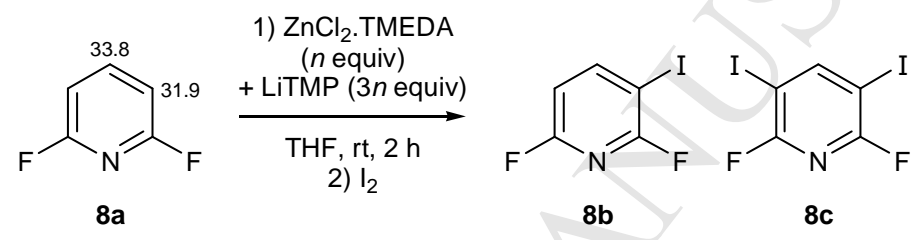

\begin{tabular}{llll}
\hline Entry & $n$ (equiv) & \multicolumn{2}{l}{ Products, yields $^{a}(\%)$} \\
\hline 1 & 0.5 & $\mathbf{8 b}, 66$ & $\mathbf{8 c},-$ \\
\hline 2 & 1 & $\mathbf{8 b},-$ & $\mathbf{8 c}, 85$ \\
\hline
\end{tabular}

${ }^{a}$ Yield after purification by column chromatography.

Compared with 2,6-dimethoxypyridine (6a), 8a is more prone to dimetalation, probably in relation with lower $\mathrm{p} K_{\mathrm{a}}$ values. Compared with $\mathbf{8 a}$, pyridines bearing heavier halogens (chlorine, bromine) give under similar reaction conditions more than one product, ${ }^{10 \mathrm{e}}$ a result probably resulting from both steric and longer range acidifying effects. ${ }^{45}$

Finally, we have shown that it is possible to associate deprotometalation-iodination of pyridines with $N$-arylation of azoles for the generation of $\mathrm{C}, \mathrm{N}$ '-linked bis-heterocycles. To this purpose, after hydrolysis and work-up, we involved the crude containing the iodide $\mathbf{5 b}$ in the reaction with pyrazole (2 equiv) using metal copper ( 0.2 equiv) as transition metal, cesium carbonate ( 2 equiv) as base, and acetonitrile as solvent at its reflux temperature for $24 \mathrm{~h}^{46}$ Under these conditions, both substitution of fluorine and $N$-arylation were noted, as evidenced with the formation of $\mathbf{5 d}$ in $70 \%$ yield (Scheme 4). 


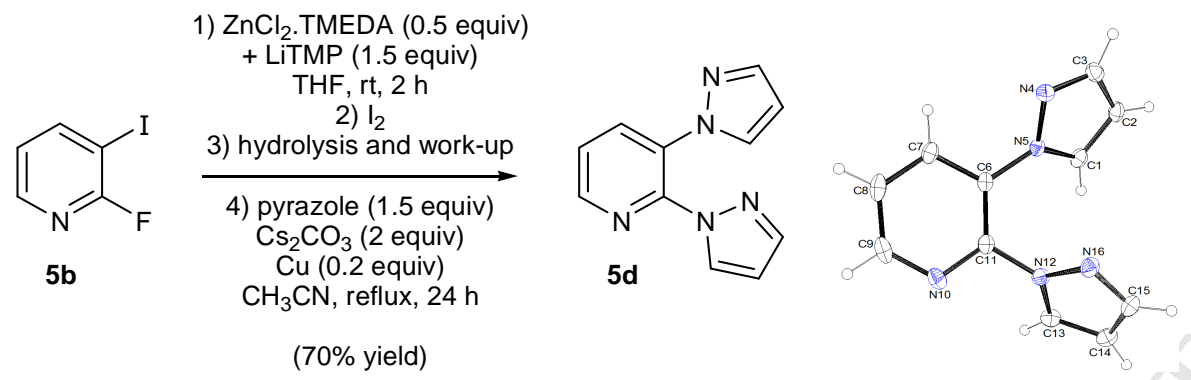

Scheme 4. Deprotometalation-iodination of $\mathbf{5 a}$ followed by $N$-arylation of pyrazole with the crude iodide $\mathbf{5 b}$ and ORTEP diagram (30\% probability) of $\mathbf{5 d}$.

\section{Conclusion}

In summary, the basic mixture prepared from 1:3 $\mathrm{ZnCl}_{2}$.TMEDA-LiTMP, and supposed to be a 1:1 mixture of LiTMP and $\mathrm{Zn}(\mathrm{TMP})_{2}$, allows reactions that are not reached by its lithium precursor. Besides more efficient monodeprotonations, for example from 2-methoxypyridine, dideprotonations can be efficiently achieved for substrates benefiting from lower $\mathrm{p} K_{\mathrm{a}}$ values such as 3 -fluoropyridine and 2,6-difluoropyridine. Such results are in accordance with a "trans-metal trapping" 12 allowing the pyridyllithiums to be trapped by zinc species as they are formed.

\section{Experimental}

\subsection{General}

All the reactions were performed in Schlenk tubes under an argon atmosphere. THF was distilled over sodium/benzophenone. Liquid chromatography separations were achieved on silica gel MerckGeduran Si $60(63-200 \mu \mathrm{m})$. Melting points were measured on a Kofler apparatus. IR spectra were taken on a Perkin-Elmer Spectrum 100 spectrometer. ${ }^{1} \mathrm{H}$ and ${ }^{13} \mathrm{C}$ Nuclear Magnetic Resonance (NMR) spectra were recorded on a Bruker Avance III spectrometer at 300 and $75 \mathrm{MHz}$, respectively. ${ }^{1} \mathrm{H}$ chemical shifts $(\delta)$ are given in ppm relative to the solvent residual peak, and ${ }^{13} \mathrm{C}$ chemical shifts are relative to the central peak of the solvent signal. ${ }^{47}$

\subsubsection{Crystallography}


The sample was studied with graphite monochromatized Mo-K $\alpha$ radiation $(\lambda=0.71073 \AA)$. The Xray diffraction data were collected by using either APEXII, Bruker-AXS diffractometer (compounds 1d, 2d and 5d) or D8 VENTURE Bruker AXS diffractometer (compounds $\mathbf{6 c}$ and $\mathbf{7 b}$ ). The structure was solved by direct methods using the SIR97 program, ${ }^{48}$ and then refined with full-matrix least-square methods based on $F^{2}$ (SHELX-97) ${ }^{49}$ with the aid of the WINGX program. ${ }^{50}$ All non-hydrogen atoms were refined with anisotropic atomic displacement parameters. $\mathrm{H}$ atoms were finally included in their calculated positions. Molecular diagrams were generated by ORTEP-3 (version 2.02). ${ }^{50}$

4.2. General procedure 1: To a stirred, cooled $\left(0^{\circ} \mathrm{C}\right)$ solution of $2,2,6,6$-tetramethylpiperidine $(0.25$ $\mathrm{mL}, 1.5 \mathrm{mmol})$ in THF (2-3 mL) were successively added BuLi (about 1.6 M hexanes solution, 1.5 $\mathrm{mmol})$ and, $5 \mathrm{~min}$ later, $\mathrm{ZnCl}_{2} \cdot \mathrm{TMEDA}^{51}(0.13 \mathrm{~g}, 0.50 \mathrm{mmol})$. The mixture was stirred for $15 \mathrm{~min}$ at 0 ${ }^{\circ} \mathrm{C}$ before introduction of the substrate $(1.0 \mathrm{mmol})$ at $0-10{ }^{\circ} \mathrm{C}$. After $2 \mathrm{~h}$ at room temperature, a solution of $\mathrm{I}_{2}(0.38 \mathrm{~g}, 1.5 \mathrm{mmol})$ in THF ( $\left.4 \mathrm{~mL}\right)$ was added. The mixture was stirred overnight before addition of an aqueous saturated solution of $\mathrm{Na}_{2} \mathrm{~S}_{2} \mathrm{O}_{3}(4 \mathrm{~mL})$ and extraction with AcOEt $(3 \times 20 \mathrm{~mL})$. The combined organic layers were dried over $\mathrm{MgSO}_{4}$, filtered and concentrated under reduced pressure. Purification by chromatography on silica gel (the eluent is given in the product description) led to the compounds described below.

4.2.1. 2-Iodo-3-methoxypyridine (1b). The general procedure 1, but with a 10 min contact time between the base and the substrate instead of $2 \mathrm{~h}$, using 3-methoxypyridine $(0.10 \mathrm{~mL})$ gave $\mathbf{1 b}$ (eluent: heptane-AcOEt 20:80) in 50\% yield as a yellow oil: ${ }^{1} \mathrm{H}$ NMR $\left(\mathrm{CDCl}_{3}\right) \delta 3.86(\mathrm{~s}, 3 \mathrm{H}), 6.97(\mathrm{dd}, 1 \mathrm{H}, J=$ 8.1 and $1.5 \mathrm{~Hz}), 7.17(\mathrm{dd}, 1 \mathrm{H}, J=8.1$ and $4.5 \mathrm{~Hz}), 7.95(\mathrm{dd}, 1 \mathrm{H}, J=4.5$ and $1.5 \mathrm{~Hz}) ;{ }^{13} \mathrm{C} \mathrm{NMR}$ $\left(\mathrm{CDCl}_{3}\right) \delta 56.4\left(\mathrm{CH}_{3}\right), 111.6(\mathrm{C}), 116.9(\mathrm{CH}), 123.6(\mathrm{CH}), 142.5(\mathrm{CH}), 155.3(\mathrm{C})$. These data are in accordance with those previously described. ${ }^{52}$

4.2.2. 4-Iodo-3-methoxypyridine (1c). The general procedure 1 using 3-methoxypyridine $(0.10 \mathrm{~mL})$ gave 1c (eluent: heptane-AcOEt 20:80) in $85 \%$ yield as a pale yellow powder: mp $88-90{ }^{\circ} \mathrm{C}$; IR (ATR): 720, 815, 1015, 1065, 1196, 1250, 1281, 1403, 1473, $1558 \mathrm{~cm}^{-1} ;{ }^{1} \mathrm{H}$ NMR $\left(\mathrm{CDCl}_{3}\right) \delta 3.98(\mathrm{~s}, 3 \mathrm{H}), 7.72$ 
$(\mathrm{d}, 1 \mathrm{H}, J=5.1 \mathrm{~Hz}), 7.87(\mathrm{~d}, 1 \mathrm{H}, J=5.1 \mathrm{~Hz}), 8.10(\mathrm{~s}, 1 \mathrm{H})$. The ${ }^{1} \mathrm{H}$ NMR data are in accordance with those previously described. ${ }^{23}{ }^{13} \mathrm{C}$ NMR $\left(\mathrm{CDCl}_{3}\right) \delta 57.1\left(\mathrm{CH}_{3}\right), 97.4(\mathrm{C}), 132.9(\mathrm{CH}), 134.4(\mathrm{CH}), 143.0$ $(\mathrm{CH}), 155.2(\mathrm{C})$.

4.2.3. 3-Fluoro-2-iodopyridine (2b). The general procedure 1 using 3 -fluoropyridine $(86 \mu \mathrm{L})$ gave 2b (eluent: $\left.\mathrm{CH}_{2} \mathrm{Cl}_{2}\right)$ in $57 \%$ yield as a yellow oil: ${ }^{1} \mathrm{H} \mathrm{NMR}\left(\mathrm{CDCl}_{3}\right) \delta 7.29-7.42(\mathrm{~m}, 2 \mathrm{H}), 8.25(\mathrm{dt}, 1 \mathrm{H}, J$ $=4.5$ and $1.5 \mathrm{~Hz}$ ). The ${ }^{1} \mathrm{H}$ NMR data are in accordance with those previously described. ${ }^{53}$

4.2.4. 3-Iodo-4-methoxypyridine (3b). The general procedure 1 using 4-methoxypyridine $(0.10 \mathrm{~mL})$ gave 3b (eluent: heptane-AcOEt 20:80) in $89 \%$ yield as a pale yellow powder: mp $62-64{ }^{\circ} \mathrm{C}$ (lit. ${ }^{10 \mathrm{~h}} 64$ $\left.{ }^{\circ} \mathrm{C}\right) ;{ }^{1} \mathrm{H} \mathrm{NMR}\left(\mathrm{CDCl}_{3}\right) \delta 3.95(\mathrm{~s}, 3 \mathrm{H}), 6.78(\mathrm{~d}, 1 \mathrm{H}, J=5.7 \mathrm{~Hz}), 8.40(\mathrm{~d}, 1 \mathrm{H}, J=5.4 \mathrm{~Hz}), 8.75(\mathrm{~s}, 1 \mathrm{H})$. The ${ }^{1} \mathrm{H}$ NMR data are in accordance with those previously reported. ${ }^{10 \mathrm{~h}}{ }^{13} \mathrm{C} \mathrm{NMR}\left(\mathrm{CDCl}_{3}\right) \delta 55.7\left(\mathrm{CH}_{3}\right)$, $84.6(\mathrm{C}), 106.5(\mathrm{CH}), 150.1(\mathrm{CH}), 156.8(\mathrm{CH}), 163.2(\mathrm{C})$.

4.2.5. 2-Fluoro-3,6-diiodopyridine (5c). The general procedure 1 using 2 -fluoropyridine $(86 \mu \mathrm{L})$ gave 5c (eluent: heptane-AcOEt 10:90) in $15 \%$ yield as a pale yellow powder: mp $88^{\circ} \mathrm{C}\left(\right.$ lit..$\left.^{10 \mathrm{~d}} 89^{\circ} \mathrm{C}\right)$; IR (ATR): 671, 727, 823, 871, 1010, 1114, 1135, 1226, 1257, 1368, 1416, 1531, 1548, $3508 \mathrm{~cm}^{-1} ;{ }^{1} \mathrm{H}$ $\operatorname{NMR}\left(\mathrm{CDCl}_{3}\right) \delta 7.38(\mathrm{dd}, 1 \mathrm{H}, J=7.8 \mathrm{~Hz}), 7.75(\mathrm{t}, 1 \mathrm{H}, J=8.0 \mathrm{~Hz})$. These ${ }^{1} \mathrm{H}$ NMR data are in accordance with those previously described. ${ }^{10 \mathrm{~d}}$

4.2.6. 2,6-Difluoro-3-iodopyridine (8b). The general procedure 1 using 2,6-difluoropyridine $(91 \mu \mathrm{L})$ gave 8b (eluent: heptane-AcOEt 10:90) in 66\% yield as a white powder: mp $<50{ }^{\circ} \mathrm{C} ;{ }^{1} \mathrm{H} \mathrm{NMR}\left(\mathrm{CDCl}_{3}\right)$ $\delta 6.69(\mathrm{ddd}, 1 \mathrm{H}, J=8.4,3.0$ and $0.9 \mathrm{~Hz}), 8.19(\mathrm{td}, 1 \mathrm{H}, J=8.1$ and $7.8 \mathrm{~Hz}) ;{ }^{13} \mathrm{C} \mathrm{NMR}\left(\mathrm{CDCl}_{3}\right) \delta 69.3$ (dd, C, $J=40$ and $5.9 \mathrm{~Hz}), 108.4(\mathrm{dd}, \mathrm{CH}, J=35$ and $5.9 \mathrm{~Hz}), 153.6(\mathrm{dd}, \mathrm{CH}, J=7.4 \mathrm{~Hz}), 160.3(\mathrm{dd}$, $\mathrm{C}, J=241$ and $14 \mathrm{~Hz}), 162.0(\mathrm{dd}, \mathrm{C}, J=247$ and $13 \mathrm{~Hz})$. These data are in accordance with those previously reported. ${ }^{30}$

4.3. General procedure 2: To a stirred, cooled $\left(0{ }^{\circ} \mathrm{C}\right)$ solution of $2,2,6,6$-tetramethylpiperidine $(0.50$ $\mathrm{mL}, 3.0 \mathrm{mmol}$ ) in THF (5 mL) were successively added BuLi (about 1.6 M hexanes solution, 3.0 mmol) and, $5 \mathrm{~min}$ later, $\mathrm{ZnCl}_{2} \cdot \mathrm{TMEDA}^{51}(0.26 \mathrm{~g}, 1.0 \mathrm{mmol})$. The mixture was stirred for $15 \mathrm{~min}$ at 0 
${ }^{\circ} \mathrm{C}$ before introduction of the substrate $(0.5 \mathrm{mmol})$ at $0-10{ }^{\circ} \mathrm{C}$. After $2 \mathrm{~h}$ at room temperature, a solution of $\mathrm{I}_{2}(0.76 \mathrm{~g}, 3.0 \mathrm{mmol})$ in THF $(8 \mathrm{~mL})$ was added. The mixture was stirred overnight before addition of an aqueous saturated solution of $\mathrm{Na}_{2} \mathrm{~S}_{2} \mathrm{O}_{3}(8 \mathrm{~mL})$ and extraction with AcOEt $(3 \times 30 \mathrm{~mL})$. The combined organic layers were dried over $\mathrm{MgSO}_{4}$, filtered and concentrated under reduced pressure. Purification by chromatography on silica gel (the eluent is given in the product description) led to the compounds described below.

4.3.1. 2,4-Diiodo-3-methoxypyridine (1d). ${ }^{10 \mathrm{~h}}$ The general procedure 2 using 3 -methoxypyridine (50 $\mu \mathrm{L}$ ) gave 1d (eluent: heptane-AcOEt 20:80) in 35\% yield as a pale yellow powder: mp 146-148 ${ }^{\circ} \mathrm{C}$; IR (ATR): $698,810,840,919,978,1012,1185,1247,1358,1452,1523,1540,1717,2931,3345 \mathrm{~cm}^{-1} ;{ }^{1} \mathrm{H}$ $\operatorname{NMR}\left(\mathrm{CDCl}_{3}\right) \delta 3.92(\mathrm{~s}, 3 \mathrm{H}), 7.66(\mathrm{~d}, 1 \mathrm{H}, J=5.1 \mathrm{~Hz}), 7.74(\mathrm{~d}, 1 \mathrm{H}, J=5.1 \mathrm{~Hz}) ;{ }^{13} \mathrm{C} \mathrm{NMR}\left(\mathrm{CDCl}_{3}\right) \delta$ $61.2\left(\mathrm{CH}_{3}\right), 100.9(\mathrm{C}), 115.2(\mathrm{C}), 134.3(\mathrm{CH}), 146.8(\mathrm{CH}), 157.1(\mathrm{C})$. Crystal data for $1 \mathrm{~d}(\mathrm{CCDC}$ 1450720, room temperature): $\mathrm{C}_{6} \mathrm{H}_{5} \mathrm{I}_{2} \mathrm{NO}, M=360.91$, orthorhombic, $P$ b $c a, a=13.2964(7), b=$ 8.6329(3), $c=15.5558(7) \AA, V=1785.60(14) \AA^{3}, Z=8, d=2.685 \mathrm{~g} \mathrm{~cm}^{-3}, \mu=6.982 \mathrm{~mm}^{-1}$. A final refinement on $F^{2}$ with 2035 unique intensities and 93 parameters converged at $\omega R\left(F^{2}\right)=0.0730(R(F)=$ 0.0311 ) for 1679 observed reflections with $I>2 \sigma(I)$.

4.3.2. 3-Fluoro-2,4-diiodopyridine (2d). The general procedure 2 using 3 -fluoropyridine $(43 \mu \mathrm{L})$ gave 2d (eluent: heptane-AcOEt 90:10) in 94\% yield as a yellow powder: mp $102{ }^{\circ} \mathrm{C}\left(\right.$ lit. $\left.{ }^{54} 102{ }^{\circ} \mathrm{C}\right) ;{ }^{1} \mathrm{H}$ $\operatorname{NMR}\left(\mathrm{CDCl}_{3}\right) \delta 7.63(\mathrm{dd}, 1 \mathrm{H}, J=4.8$ and $4.2 \mathrm{~Hz}), 7.82(\mathrm{dd}, 1 \mathrm{H}, J=5.1$ and $0.9 \mathrm{~Hz}) ;{ }^{13} \mathrm{C} \mathrm{NMR}$ $\left(\mathrm{CDCl}_{3}\right) \delta 91.1(\mathrm{~d}, \mathrm{C}, J=17 \mathrm{~Hz}), 105.4(\mathrm{~d}, \mathrm{C}, J=32 \mathrm{~Hz}), 134.0(\mathrm{~d}, \mathrm{CH}, J=1.1 \mathrm{~Hz}), 146.9(\mathrm{~d}, \mathrm{CH}, J=$ $6.2 \mathrm{~Hz}), 158.6(\mathrm{~d}, \mathrm{C}, J=254 \mathrm{~Hz})$. Crystal data for $2 \mathrm{~d}(\mathrm{CCDC} 1450721, \mathrm{~T}=150 \mathrm{~K}): \mathrm{C}_{5} \mathrm{H}_{2} \mathrm{FI}_{2} \mathrm{~N}, M=$ 348.88, triclinic, $P-1, a=7.1039(4), b=7.8955(5), c=7.9442(5) \AA, \alpha=109.945(2), \beta=105.973(2), \gamma$ $=102.495(2)^{\circ}, V=378.21(4) \AA^{3}, Z=2, d=3.063 \mathrm{~g} \mathrm{~cm}^{-3}, \mu=8.244 \mathrm{~mm}^{-1}$. A final refinement on $F^{2}$ with 1737 unique intensities and 83 parameters converged at $\omega R\left(F^{2}\right)=0.1171(R(F)=0.0389)$ for 1639 observed reflections with $I>2 \sigma(I)$. 
4.3.3. 3,5-Diiodo-2,6-dimethoxypyridine (6c). The general procedure 2 , but with a contact time of $20 \mathrm{~h}$ with the base, using 2,6-dimethoxypyridine $(66 \mu \mathrm{L})$ gave $6 \mathbf{c}$ (eluent: heptane- $\mathrm{CH}_{2} \mathrm{Cl}_{2}$ 60:40) in $30 \%$ yield as a pale yellow powder: $\operatorname{mp} 126^{\circ} \mathrm{C}$; IR (ATR): 708, 736, 908, 999, 1038, 1235, 1247, 1288, 1315, 1385, 1361, 1459, 1552, $2948 \mathrm{~cm}^{-1} ;{ }^{1} \mathrm{H}$ NMR $\left(\mathrm{CDCl}_{3}\right) \delta 3.96(\mathrm{~s}, 6 \mathrm{H}), 8.16(\mathrm{~s}, 1 \mathrm{H}) ;{ }^{13} \mathrm{C} \mathrm{NMR}$ $\left(\mathrm{CDCl}_{3}\right) \delta 54.9\left(2 \mathrm{CH}_{3}\right), 66.8(2 \mathrm{C}), 156.8(\mathrm{CH}), 161.3(2 \mathrm{C})$. Crystal data for $6 \mathbf{c}(\mathrm{CCDC} 1450723, \mathrm{~T}=$ $150 \mathrm{~K}): \mathrm{C}_{7} \mathrm{H}_{7} \mathrm{I}_{2} \mathrm{NO}_{2}, M=390.94$, monoclinic, $P 2{ }_{l} / c, a=8.2579(3), b=8.6432(3), c=14.7789(6) \AA$ $=104.7150(10)^{\circ}, V=1020.24(7) \AA^{3}, Z=4, d=2.545 \mathrm{~g} \mathrm{~cm}^{-3}, \mu=6.128 \mathrm{~mm}^{-1}$. A final refinement on $F^{2}$ with 2337 unique intensities and 112 parameters converged at $\omega R\left(F^{2}\right)=0.0433(R(F)=0.0174)$ for 2190 observed reflections with $I>2 \sigma(I)$.

4.4. General procedure 3: To a stirred, cooled $\left(0{ }^{\circ} \mathrm{C}\right)$ solution of 2,2,6,6-tetramethylpiperidine $(0.25$ $\mathrm{mL}, 1.5 \mathrm{mmol})$ in THF (2-3 mL) were successively added BuLi (about $1.6 \mathrm{M}$ hexanes solution, 1.5 $\mathrm{mmol})$ and, $5 \mathrm{~min}$ later, $\mathrm{ZnCl}_{2} \cdot \mathrm{TMEDA}^{51}(0.13 \mathrm{~g}, 0.50 \mathrm{mmol})$. The mixture was stirred for $15 \mathrm{~min}$ at 0 ${ }^{\circ} \mathrm{C}$ before introduction of the substrate $(0.5 \mathrm{mmol})$ at $0-10{ }^{\circ} \mathrm{C}$. After $2 \mathrm{~h}$ at room temperature, a solution of $\mathrm{I}_{2}(0.38 \mathrm{~g}, 1.5 \mathrm{mmol})$ in THF $(4 \mathrm{~mL})$ was added. The mixture was stirred overnight before addition of an aqueous saturated solution of $\mathrm{Na}_{2} \mathrm{~S}_{2} \mathrm{O}_{3}(4 \mathrm{~mL})$ and extraction with AcOEt $(3 \times 20 \mathrm{~mL})$. The combined organic layers were dried over $\mathrm{MgSO}_{4}$, filtered and concentrated under reduced pressure. Purification by chromatography on silica gel (the eluent is given in the product description) led to the compounds described below.

4.4.1. 3-Fluoro-4-iodopyridine (2c). The general procedure 3 using 3 -fluoropyridine $(43 \mu \mathrm{L})$ gave 2c (eluent: hexane- $\mathrm{CH}_{2} \mathrm{Cl}_{2}$ 80:20) in $45 \%$ yield as a yellow powder: $\mathrm{mp} 94{ }^{\circ} \mathrm{C}$ (lit. ${ }^{53} 96^{\circ} \mathrm{C}$ ); IR (ATR): $1415,1475,1550,1570,3060 \mathrm{~cm}^{-1} ;{ }^{1} \mathrm{H}$ NMR $\left(\mathrm{CDCl}_{3}\right) \delta 7.75(\mathrm{t}, 1 \mathrm{H}, J=5.1 \mathrm{~Hz}), 8.10(\mathrm{~d}, 1 \mathrm{H}, J=5.1$ $\mathrm{Hz}), 8.35(\mathrm{~s}, 1 \mathrm{H}) ;{ }^{13} \mathrm{C} \mathrm{NMR}\left(\mathrm{CDCl}_{3}\right) \delta 92.4(\mathrm{~d}, \mathrm{C}, J=23 \mathrm{~Hz}), 133.7(\mathrm{~s}, \mathrm{CH}), 137.1(\mathrm{~d}, \mathrm{CH}, J=26 \mathrm{~Hz})$, $145.6(\mathrm{~d}, \mathrm{CH}, J=5.1 \mathrm{~Hz}), 159.1(\mathrm{~d}, \mathrm{C}, J=256 \mathrm{~Hz})$. 
4.4.2. 3,5-Diiodo-4-methoxypyridine (3c). The general procedure 3 using 4-methoxypyridine (51 $\mu \mathrm{L}$ ) gave 3c (eluent: heptane-AcOEt 20:80) in an estimated $7 \%$ yield. It was identified by NMR: ${ }^{1} \mathrm{H}$ $\operatorname{NMR}\left(\mathrm{CDCl}_{3}\right) \delta 3.91(\mathrm{~s}, 3 \mathrm{H}), 8.72(\mathrm{~s}, 2 \mathrm{H})$.

4.4.3. 2,3-Diiodo-4-methoxypyridine (3d). The general procedure 3 using 4-methoxypyridine (51 $\mu \mathrm{L})$ gave 3d (eluent: heptane-AcOEt 20:80) in an estimated $2 \%$ yield. It was identified by NMR: ${ }^{1} \mathrm{H}$ $\operatorname{NMR}\left(\mathrm{CDCl}_{3}\right) \delta 3.93(\mathrm{~s}, 3 \mathrm{H}), 6.68(\mathrm{~d}, 1 \mathrm{H}, J=5.4 \mathrm{~Hz}), 8.20(\mathrm{~d}, 1 \mathrm{H}, J=5.4 \mathrm{~Hz})$.

4.4.4. 2,5-Diiodo-4-methoxypyridine (3e). The general procedure 3 using 4-methoxypyridine (51 $\mu \mathrm{L})$ gave 3e (eluent: heptane-AcOEt $20: 80)$ as traces. It was identified by NMR: ${ }^{1} \mathrm{H}$ NMR $\left(\mathrm{CDCl}_{3}\right) \delta$ $3.91(\mathrm{~s}, 3 \mathrm{H}), 7.11(\mathrm{~s}, 1 \mathrm{H}), 8.44(\mathrm{~s}, 1 \mathrm{H})$.

4.4.5. 3-Iodo-2-methoxypyridine (4b). The general procedure 3 using 2 -methoxypyridine $(53 \mu \mathrm{L})$ gave 4b (eluent: heptane-AcOEt 80:20) in 98\% yield as a yellow oil: ${ }^{1} \mathrm{H} \mathrm{NMR}\left(\mathrm{CDCl}_{3}\right) \delta 3.95(\mathrm{~s}, 3 \mathrm{H})$, $6.60(\mathrm{dd}, 1 \mathrm{H}, J=7.5$ and $4.8 \mathrm{~Hz}), 7.98(\mathrm{dd}, 1 \mathrm{H}, J=7.5$ and $1.8 \mathrm{~Hz}), 8.08(\mathrm{dd}, 1 \mathrm{H}, J=5.1$ and $1.8 \mathrm{~Hz})$; ${ }^{13} \mathrm{C}$ NMR $\left(\mathrm{CDCl}_{3}\right) \delta 54.7\left(\mathrm{CH}_{3}\right), 79.9(\mathrm{C}), 118.3(\mathrm{CH}), 146.5(\mathrm{CH}), 148.0(\mathrm{CH}), 161.9(\mathrm{C})$. These NMR data are in accordance with those previously described. ${ }^{36}$

4.4.6. 2-Fluoro-3-iodopyridine (5b). The general procedure 3 using 2 -fluoropyridine ( $43 \mu \mathrm{L})$ gave 5b (eluent: heptane-AcOEt 10:90) in $82 \%$ yield as a white powder: $\mathrm{mp}<50{ }^{\circ} \mathrm{C}$; IR (ATR): 737, 794, $843,1018,1065,1137,1253,1370,1407,1424,1557,1576,3383 \mathrm{~cm}^{-1} ;{ }^{1} \mathrm{H}$ NMR $\left(\mathrm{CDCl}_{3}\right) \delta 6.93(\mathrm{ddd}$, $1 \mathrm{H}, J=7.5,5.1$ and $2.1 \mathrm{~Hz}), 8.09-8.16(\mathrm{~m}, 2 \mathrm{H})$. These data are in accordance with those described previously. ${ }^{10 \mathrm{~d}}$

4.4.7. 3-Iodo-2,6-dimethoxypyridine (6b). The general procedure 3 using 3-methoxypyridine (50 $\mu \mathrm{L}$ ) gave 6b (eluent: heptane-AcOEt 10:90) in 98\% yield as a yellow oil: IR (ATR): 670, 807, 950, 1002, 1020, 1050, 1112, 1191, 1234, 1265, 1309, 1372, 1411, 1462, 1567, 2948, $2985 \mathrm{~cm}^{-1} ;{ }^{1} \mathrm{H}$ NMR $\left(\mathrm{CDCl}_{3}\right) \delta 3.89(\mathrm{~s}, 3 \mathrm{H}), 3.96(\mathrm{~s}, 3 \mathrm{H}), 6.15(\mathrm{~d}, 1 \mathrm{H}, J=8.1 \mathrm{~Hz}), 7.80(\mathrm{~d}, 1 \mathrm{H}, J=8.1 \mathrm{~Hz}) ;{ }^{13} \mathrm{C} \mathrm{NMR}$ $\left(\mathrm{CDCl}_{3}\right) \delta 53.5\left(\mathrm{CH}_{3}\right), 54.3\left(\mathrm{CH}_{3}\right), 65.5(\mathrm{C}), 103.4(\mathrm{CH}), 149.3(\mathrm{CH}), 160.5(\mathrm{C}), 163.1(\mathrm{C})$. These data are in accordance with those previously described. ${ }^{36}$ 
4.4.8. 4-Iodo-2,3-dimethoxypyridine (7b). The general procedure 3 using 3-methoxypyridine (50 $\mu \mathrm{L}$ ) gave 7b (eluent: heptane-AcOEt 10:90) in $98 \%$ yield as a pale yellow powder: $\mathrm{mp}<50{ }^{\circ} \mathrm{C}$; IR (ATR): 659, 769, 819, 855, 986, 1020, 1157, 1215, 1383, 1460, 1562, $2938 \mathrm{~cm}^{-1} ;{ }^{1} \mathrm{H} \mathrm{NMR}\left(\mathrm{CDCl}_{3}\right) \delta$ $3.83(\mathrm{~s}, 3 \mathrm{H}), 3.96(\mathrm{~s}, 3 \mathrm{H}), 7.22(\mathrm{~d}, 1 \mathrm{H}, J=5.4 \mathrm{~Hz}), 7.51(\mathrm{~d}, 1 \mathrm{H}, J=5.4 \mathrm{~Hz}) ;{ }^{13} \mathrm{C} \mathrm{NMR}\left(\mathrm{CDCl}_{3}\right) \delta 53.7$ $\left(\mathrm{CH}_{3}\right), 60.0\left(\mathrm{CH}_{3}\right), 101.7(\mathrm{C}), 126.6(\mathrm{CH}), 141.4(\mathrm{CH}), 144.3(\mathrm{C}), 156.8(\mathrm{C})$. Crystal data for $7 \mathrm{~b}$ $(\mathrm{CCDC} 1450724, \mathrm{~T}=150 \mathrm{~K}): \mathrm{C}_{7} \mathrm{H}_{8} \mathrm{INO}_{2}, M=265.04$, orthorhombic, $P \quad b \quad c a, a=8.0585(4), b=$ 13.4414(6), $c=15.7058(7) \AA, V=1701.21(14) \AA^{3}, Z=8, d=2.070 \mathrm{~g} \mathrm{~cm}^{-3}, \mu=3.715 \mathrm{~mm}^{-1}$. A final refinement on $F^{2}$ with 1957 unique intensities and 102 parameters converged at $\omega R\left(F^{2}\right)=0.0408(R(F)$ $=0.0177)$ for 1730 observed reflections with $I>2 \sigma(I)$.

4.4.9. 2,6-Difluoro-3,5-diiodopyridine (8c). The general procedure 3 using 2,6-difluoropyridine (45 $\mu \mathrm{L}$ ) gave 8c (eluent: heptane-AcOEt 10:90) in $85 \%$ yield as a pale yellow powder: $\mathrm{mp} 102{ }^{\circ} \mathrm{C}$; IR (ATR): 666, 728, 811, 1047, 1268, 1363, 1423, 1567, $2922 \mathrm{~cm}^{-1} ;{ }^{1} \mathrm{H}$ NMR $\left(\mathrm{CDCl}_{3}\right) \delta 8.50(\mathrm{t}, 1 \mathrm{H}, J=$ $7.7 \mathrm{~Hz}) ;{ }^{13} \mathrm{C} \mathrm{NMR}\left(\mathrm{CDCl}_{3}\right) \delta 70.7-71.3(\mathrm{~m}, 2 \mathrm{C}), 160.6(\mathrm{t}, \mathrm{CH}, J=2.8 \mathrm{~Hz}), 160.7(\mathrm{dd}, 2 \mathrm{C}, J=243$ and $13 \mathrm{~Hz})$.

4.5. General procedure 4: To a stirred, cooled $\left(0{ }^{\circ} \mathrm{C}\right)$ solution of 2,2,6,6-tetramethylpiperidine $(0.25$ $\mathrm{mL}, 1.5 \mathrm{mmol}$ ) in THF (2-3 mL) were successively added BuLi (about $1.6 \mathrm{M}$ hexanes solution, 1.5 mmol) and, $5 \mathrm{~min}$ later, $\mathrm{ZnCl}_{2} \cdot \mathrm{TMEDA}^{51}(0.13 \mathrm{~g}, 0.50 \mathrm{mmol})$. The mixture was stirred for $15 \mathrm{~min}$ at 0 ${ }^{\circ} \mathrm{C}$ before introduction of the substrate $(1.0 \mathrm{mmol})$ at $0-10{ }^{\circ} \mathrm{C}$. After $2 \mathrm{~h}$ at room temperature, a solution of $\mathrm{I}_{2}(0.38 \mathrm{~g}, 1.5 \mathrm{mmol})$ in THF ( $\left.4 \mathrm{~mL}\right)$ was added. The mixture was stirred overnight before addition of an aqueous saturated solution of $\mathrm{Na}_{2} \mathrm{~S}_{2} \mathrm{O}_{3}(4 \mathrm{~mL})$ and extraction with AcOEt $(3 \times 20 \mathrm{~mL})$. The combined organic layers were dried over $\mathrm{MgSO}_{4}$, filtered and concentrated under reduced pressure. To the crude iodide were added $\mathrm{Cs}_{2} \mathrm{CO}_{3}(0.65 \mathrm{~g}, 2.0 \mathrm{mmol}), \mathrm{Cu}$ powder $(13 \mathrm{mg}, 0.20 \mathrm{mmol})$, the azole $(1.5$ mmol) and $\mathrm{MeCN}(5 \mathrm{~mL})$ and the resulting mixture was heated under reflux for $24 \mathrm{~h}$. Filtration over celite $^{\circledR}$, washing with AcOEt, removal of the solvent and purification by chromatography on silica gel (the eluent is given in the product description) led to the compound described below. 
4.5.1. 2,3-Bis(1H-1-pyrazolyl)pyridine (5d). The general procedure 4 using 2-fluoropyridine (86 $\mu \mathrm{L})$ and pyrazole $(0.10 \mathrm{~mL})$ gave 5d (eluent: heptane-AcOEt 90:10) in 70\% yield as a yellow powder: mp $98{ }^{\circ} \mathrm{C}$; IR (ATR): 757, 808, 937, 1018, 1036, 1050, 1262, 1297, 1393, 1458, 1479, 1521, 1584, 3090, $3122 \mathrm{~cm}^{-1} ;{ }^{1} \mathrm{H}$ NMR $\left(\mathrm{CDCl}_{3}\right) \delta 6.29(\mathrm{t}, 1 \mathrm{H}, J=2.3 \mathrm{~Hz}), 6.34(\mathrm{t}, 1 \mathrm{H}, J=2.3 \mathrm{~Hz}), 7.06(\mathrm{~d}, 1 \mathrm{H}, J=$ $2.4 \mathrm{~Hz}), 7.40(\mathrm{dd}, 1 \mathrm{H}, J=8.1$ and $4.8 \mathrm{~Hz}), 7.61-7.67(\mathrm{~m}, 3 \mathrm{H}), 8.05(\mathrm{dd}, 1 \mathrm{H}, J=7.8$ and $1.5 \mathrm{~Hz}), 8.50$ $(\mathrm{dd}, 1 \mathrm{H}, J=4.8$ and $1.8 \mathrm{~Hz}) ;{ }^{13} \mathrm{C} \mathrm{NMR}\left(\mathrm{CDCl}_{3}\right) \delta 107.6(\mathrm{CH}), 107.7(\mathrm{CH}), 123.6(\mathrm{CH}), 129.8(\mathrm{CH})$, $130.2(\mathrm{C}), 130.6(\mathrm{CH}), 136.2(\mathrm{CH}), 141.5(\mathrm{CH}), 142.0(\mathrm{CH}), 144.9(\mathrm{C}), 147.8(\mathrm{CH})$. Crystal data for 5d $(\mathrm{CCDC} 1450722, \mathrm{~T}=150 \mathrm{~K}): \mathrm{C}_{11} \mathrm{H}_{9} \mathrm{~N}_{5}, M=211.23$, orthorhombic, $P 2_{1} 2_{1} 2_{1}, a=8.7934(9), b=$ 8.9384(7), $c=13.0819(14) \AA, V=1028.22(17) \AA^{3}, Z=4, d=1.365 \mathrm{~g} \mathrm{~cm}^{-3}, \mu=0.090 \mathrm{~mm}^{-1}$. A final refinement on $F^{2}$ with 1369 unique intensities and 145 parameters converged at $\omega R\left(F^{2}\right)=0.0937(R(F)$ $=0.0392)$ for 1211 observed reflections with $I>2 \sigma(I)$.

Acknowledgments. This work was supported by the Ministère de l'Enseignement supérieur et de la Recherche scientifique Algérien (M. H.). F. M. thanks the Institut Universitaire de France and also Thermo Fisher for the generous gift of 2,2,6,6-tetramethylpiperidine. T. R. and V. D. thank FEDER founds (D8 VENTURE Bruker AXS diffractometer).

Supplementary data. Supplementary data associated with this article can be found in the online version, at http://dx.doi.org/10.1016/j.tet.xxxxxxxxxxxxxxxxxxxxxxxxxxxxxxxxxxxxxxxxxx.

\section{References and Notes}

1. Eicher, T.; Hauptmann, S.; Speicher, A., The Chemistry of Heterocycles, $2^{\text {nd }}$ ed., Wiley-VCH, New York, 2003.

2. See for example: (a) Kim, M.; Lee, J. Y. Chem. Asian J. 2012, 7, 899-902; (b) Lin, H.-W.; Lu, C.-W.; Lin, L.-Y.; Chen, Y.-H.; Lin, W.-C.; Wong, K.-T.; Lin, F. J. Mater. Chem. A 2013, 1, 1770-1777.

3. (a) Gschwend, H. W.; Rodriguez, H. R. Org. React. 1979, 26, 1-360; (b) Beak, P.; Snieckus, V. Acc. Chem. Res. 1982, 15, 306-312; (c) Snieckus, V. Chem. Rev. 1990, 90, 879-933; (d) Gant, T. G.; Meyers, A. I. Tetrahedron 1994, 50, 2297-2360; (e) Schlosser, M. Organometallics in Synthesis 2002, 2nd ed. (Ed.: M. Schlosser), Wiley: New York, Chapter I. 
4. (a) Queguiner, G.; Marsais, F.; Snieckus, V.; Epsztajn, J. Adv. Heterocycl. Chem. 1991, 52, 187-304; (b) Mongin, F.; Queguiner, G. Tetrahedron 2001, 57, 4059-4090; (c) Schlosser, M.; Mongin, F. Chem. Soc. Rev. 2007, 36, 1161-1172.

5. (a) Mulvey, R. E. Acc. Chem. Res. 2009, 42, 743-755; (b) Haag, B.; Mosrin, M.; Ila, H.; Malakhov, V.; Knochel, P. Angew. Chem. Int. Ed. 2011, 50, 9794-9824; (c) Mongin, F.; Harrison-Marchand, A. Chem. Rev. 2013, 113, 7563-7727.

6. (a) Gros, P.; Fort, Y. Eur. J. Org. Chem. 2002, 3375-3383; (b) Gros, P. C.; Fort, Y. Eur. J. Org. Chem. 2009, 4199-4209.

7. Harford, P. J.; Peel, A. J.; Chevallier, F.; Takita, R.; Mongin, F.; Uchiyama, M.; Wheatley, A. E. H. Dalton Trans. 2014, 43, 14181-14203.

8. (a) Mulvey, R. E.; Mongin, F.; Uchiyama, M.; Kondo, Y. Angew. Chem. Int. Ed. 2007, 46, 3802-3824; (b) Wunderlich, S. H.; Knochel, P. Angew. Chem. Int. Ed. 2007, 46, 7685-7688; (c) Jaric, M.; Haag, B. A.; Unsinn, A.; Karaghiosoff, K.; Knochel, P. Angew. Chem. Int. Ed. 2010, 49, 5451-5455.

9. Mongin, F.; Uchiyama, M. Curr. Org. Chem. 2011, 15, 2340-2361.

10. (a) L'Helgoual'ch, J. M.; Seggio, A.; Chevallier, F.; Yonehara, M.; Jeanneau, E.; Uchiyama, M.; Mongin, F. J. Org. Chem. 2008, 73, 177-183; (b) Seggio, A.; Lannou, M.-I.; Chevallier, F.; Nobuto, D.; Uchiyama, M.; Golhen, S.; Roisnel, T.; Mongin, F. Chem. Eur. J. 2007, 13, 99829989; (c) Seggio, A.; Chevallier, F.; Vaultier, M.; Mongin, F. J. Org. Chem. 2007, 72, 66026605; (d) Snégaroff, K.; Komagawa, S.; Chevallier, F.; Gros, P. C.; Golhen, S.; Roisnel, T.; Uchiyama, M.; Mongin, F. Chem. Eur. J. 2010, 16, 8191-8201; (e) Snégaroff, K.; Nguyen, T. T.; Marquise, N.; Halauko, Y. S.; Harford, P. J.; Roisnel, T.; Matulis, V. E.; Ivashkevich, O. A.; Chevallier, F.; Wheatley, A. E. H.; Gros, P. C.; Mongin, F. Chem. Eur. J. 2011, 17, 1328413297; (f) Chevallier, F.; Halauko, Y. S.; Pecceu, C.; Nassar, I. F.; Dam, T. U.; Roisnel, T.; Matulis, V. E.; Ivashkevich, O. A.; Mongin, F. Org. Biomol. Chem. 2011, 9, 4671-4684; (g) Chevallier, F.; Blin, T.; Nagaradja, E.; Lassagne, F.; Roisnel, T.; Halauko, Y. S.; Matulis, V. E.; Ivashkevich, O. A.; Mongin, F. Org. Biomol. Chem. 2012, 10, 4878-4885; (h) Kadiyala, R. R.; Tilly, D.; Nagaradja, E.; Roisnel, T.; Matulis, V. E.; Ivashkevich, O. A.; Halauko, Y. S.; Chevallier, F.; Gros, P. C.; Mongin, F. Chem. Eur. J. 2013, 19, 7944-7960; (i) Nagaradja, E.; Chevallier, F.; Roisnel, T.; Dorcet, V.; Halauko, Y. S.; Ivashkevich, O. A.; Matulis, V. E.; Mongin, F. Org. Biomol. Chem. 2014, 1475-1487; (j) Marquise, N.; Bretel, G.; Lassagne, F.; Chevallier, F.; Roisnel, T.; Dorcet, V.; Halauko, Y. S.; Ivashkevich, O. A.; Matulis, V. E.; Gros, P. C.; Mongin, F. RSC Adv. 2014, 4, 19602-19612; (k) Ameur Messaoud, M. Y.; BentabedAbabsa, G.; Hedidi, M.; Derdour, A.; Chevallier, F.; Halauko, Y. S.; Ivashkevich, O. A.; Matulis, V. E.; Picot, L.; Thiéry, V.; Roisnel, T.; Dorcet, V.; Mongin, F. Beilstein J. Org. Chem. 2015, 11, 1475-1485; (1) Nagaradja, E.; Bentabed-Ababsa, G.; Scalabrini, M.; Chevallier, F.; Philippot, S.; Fontanay, S.; Duval, R. E.; Halauko, Y. S.; Ivashkevich, O. A.; Matulis, V. E.; Roisnel, T.; Mongin, F. Bioorg. Med. Chem. 2015, 23, 6355-6363.

11. García-Álvarez, P.; Mulvey, R. E.; Parkinson, J. A. Angew. Chem. Int. Ed. 2011, 50, 96689671.

12. Fuentes, M. A.; Kennedy, A. R.; Mulvey, R. E.; Parkinson, J. A.; Rantanen, T.; Robertson, S. D.; Snieckus, V. Chem. Eur. J. 2015, 21, 14812-14822.

13. Becker, M. R.; Knochel, P. Angew. Chem. Int. Ed. 2015, 54, 12501-12505.

14. Concerning simulation of heteroaromatic $\mathrm{p} K_{\mathrm{a}}$ values in DMSO, see: Shen, K.; Fu, Y.; Li, J.-N.; Liu, L.; Guo, Q.-X. Tetrahedron 2007, 63, 1568-1576.

15. Baboul, A. G.; Curtiss, L. A.; Redfern, P. C.; Raghavachari, K. J. Chem. Phys. 1999, 110, 76507657.

16. Fraser, R. R.; Bresse, M.; Mansour, T. S. J. Am. Chem. Soc. 1983, 105, 7790-7791.

17. Hansch, C.; Leo, A.; Taft, R. W. Chem. Rev. 1991, 91, 165-195. 
18. (a) Whisler, M. C.; MacNeil, S.; Snieckus, V.; Beak, P. Angew. Chem. Int. Ed. 2004, 43, 22062225. For examples in the pyridine series, see: (b) Dhau, J. S.; Singh, A.; Kasetti, Y.; Bhatia, S.; Bharatam, P. V.; Brandão, P.; Félix, V.; Singh, K. N. Tetrahedron 2013, 69, 10284-10291.

19. Marsais, F.; Le Nard, G.; Queguiner, G. Synthesis 1982, 235-237.

20. Comins, D. L.; LaMunyon, D. H. Tetrahedron Lett. 1988, 29, 773-776.

21. Baillie, S. E.; Bluemke, T. D.; Clegg, W.; Kennedy, A. R.; Klett, J.; Russo, L.; de Tullio, M.; Hevia, E. Chem. Commun. 2014, 50, 12859-12862.

22. Kondo, Y.; Shilai, M.; Uchiyama, M.; Sakamoto, T. J. Am. Chem. Soc. 1999, 121, 3539-3540.

23. Blair, V. L.; Blakemore, D. C.; Hay, D.; Hevia, E.; Pryde, D. C. Tetrahedron Lett. 2011, 52, 4590-4594.

24. Its ${ }^{1} \mathrm{H}$ NMR spectrum proved identical to that previously described: Dehmlow, E. V.; Sleegers, A. Liebigs Ann. Chem. 1992, 953-959.

25. (a) Uchiyama, M.; Matsumoto, Y.; Nobuto, D.; Furuyama, T.; Yamaguchi, K.; Morokuma, K. J. Am. Chem. Soc. 2006, 128, 8748-8750; (b) Kondo, Y.; Morey, J. V.; Morgan, J. C.; Naka, H.; Nobuto, D.; Raithby, P. R.; Uchiyama, M.; Wheatley, A. E. H. J. Am. Chem. Soc. 2007, 129, 12734-12738.

26. Clegg, W.; Conway, B.; Hevia, E.; McCall, M. D.; Russo, L.; Mulvey, R. E. J. Am. Chem. Soc. 2009, 131, 2375-2384.

27. (a) Marsais, F.; Mallet, M.; Queguiner, G.; Pastour, P. C. R. Hebd. Séances Acad. Sci., Ser. C 1972, 275, 1535-1538; (b) Marsais, F.; Queguiner, G. Tetrahedron 1983, 39, 2009-2021.

28. Gribble, G. W.; Saulnier, M. G. Tetrahedron Lett. 1980, 21, 4137-4140.

29. Shi, G.-q.; Takagishi, S.; Schlosser, M. Tetrahedron 1994, 50, 1129-1134.

30. Awad, H.; Mongin, F.; Trécourt, F.; Queguiner, G.; Marsais, F.; Blanco, F.; Abarca, B.; Ballesteros, R. Tetrahedron Lett. 2004, 45, 6697-6701.

31. Trécourt, F.; Mallet, M.; Mongin, O.; Gervais, B.; Queguiner, G. Tetrahedron 1993, 49, 83738380.

32. Trécourt, F.; Mallet, M.; Marsais, F.; Queguiner, G. J. Org. Chem. 1988, 53, 1367-1371.

33. Thomas, E. W. J. Org. Chem. 1986, 51, 2184-2191.

34. Mallet, M. J. Organomet. Chem. 1991, 406, 49-56.

35. (a) Naka, H.; Uchiyama, M.; Matsumoto, Y.; Wheatley, A. E. H.; McPartlin, M.; Morey, J. V.; Kondo, Y. J. Am. Chem. Soc. 2007, 129, 1921-1930. Concerning the behavior of this lithiumaluminum base, see: (b) Armstrong, D. R.; Crosbie, E.; Hevia, E.; Mulvey, R. E.; Ramsay, D. L.; Robertson, S. D. Chem. Sci. 2014, 5, 3031-3045.

36. Dayaker, G.; Chevallier, F.; Gros, P. C.; Mongin, F. Tetrahedron 2010, 66, 8904-8910.

37. Nguyen, T. T.; Marquise, N.; Chevallier, F.; Mongin, F. Chem. Eur. J. 2011, 17, 10405-10416.

38. Nagaradja, E.; Chevallier, F.; Roisnel, T.; Jouikov, V.; Mongin, F. Tetrahedron 2012, 68, 30633073.

39. Gros, P.; Fort, Y.; Caubère, P. J. Chem. Soc., Perkin Trans. 1 1997, 3071-3080.

40. Marsais, F.; Granger, P.; Queguiner, G. J. Org. Chem. 1981, 46, 4494-4497.

41. (a) Güngor, T.; Marsais, F.; Queguiner, G. J. Organomet. Chem. 1981, 215, 139-150; (b) Gupta, L.; Hoepker, A. C.; Singh, K. J.; Collum, D. B. J. Org. Chem. 2009, 74, 2231-2233; (c) Gupta, L.; Hoepker, A. C.; Ma, Y.; Viciu, M. S.; Faggin, M. F.; Collum, D. B. J. Org. Chem. 2013, 78, 4214-4230.

42. Khanapure, S. P.; Biehl, E. R. Heterocycles 1990, 31, 505-516.

43. Trécourt, F.; Mallet, M.; Mongin, O.; Queguiner, G. J. Org. Chem. 1994, 59, 6173-6178.

44. (a) Schlosser, M.; Rausis, T. Eur. J. Org. Chem. 2004, 1018-1024; (b) Shutske, G. M.; Roehr, J. E. J. Heterocycl. Chem. 1997, 34, 789-795.

45. (a) Mongin, F.; Curty, C.; Marzi, E.; Leroux, F. R.; Schlosser, M. ARKIVOC 2015, 48-65; (b) Mongin, F. Chimia 2016, 70, 48-52. 
46. These conditions were used with success in: (a) Zhu, R.; Xing, L.; Wang, X.; Cheng, C.; Su, D.; Hu, Y. Adv. Synth. Catal. 2008, 350, 1253-1257. See also: (b) Hedidi, M.; Bentabed-Ababsa, G.; Derdour, A.; Roisnel, T.; Dorcet, V.; Chevallier, F.; Picot, L.; Thiéry, V.; Mongin, F. Bioorg. Med. Chem. 2014, 22, 3498-3507.

47. Gottlieb, H. E.; Kotlyar, V.; Nudelman, A. J. Org. Chem. 1997, 62, 7512-7515.

48. Altomare, A.; Burla, M. C.; Camalli, M.; Cascarano, G. L.; Giacovazzo, C.; Guagliardi, A.; Moliterni, A. G. G.; Polidori, G.; Spagna, R. J. Appl. Crystallogr. 1999, 32, 115-119.

49. Sheldrick, G. M. Acta Crystallogr., Sect. A 2008, A64, 112-122.

50. Farrugia, L. J. J. Appl. Crystallogr. 2012, 45, 849-854.

51. Isobe, M.; Kondo, S.; Nagasawa, N.; Goto, T. Chem. Lett. 1977, 679-682.

52. $\quad$ Mongin, F.; Trécourt, F.; Mongin, O.; Queguiner, G. Tetrahedron 2002, 58, 309-314.

53. Rocca, P.; Marsais, F.; Godard, A.; Queguiner, G. Tetrahedron 1993, 49, 49-64.

54. Rocca, P.; Cochennec, C.; Marsais, F.; Thomas-dit-Dumont, L.; Mallet, M.; Godard, A.; Queguiner, G. J. Org. Chem. 1993, 58, 7832-7838. 